\title{
Technical Basis Document
}

\section{Estimation of Radiation Doses in the Marshall Islands Based on Whole Body Counting of Cesium-137 ( $\left.{ }^{137} \mathrm{Cs}\right)$ and Plutonium Urinalysis}

\author{
J.I. Daniels \\ D.P. Hickman \\ S.R. Kehl \\ T.F. Hamilton
}

September 2007 


\section{DISCLAIMER}

This document was prepared as an account of work sponsored by an agency of the United States Government. Neither the United States Government nor the University of California nor any of their employees, makes any warranty, express or implied, or assumes any legal liability or responsibility for the accuracy, completeness, or usefulness of any information, apparatus, product, or process disclosed, or represents that its use would not infringe privately owned rights. Reference herein to any specific commercial product, process, or service by trade name, trademark, manufacturer, or otherwise, does not necessarily constitute or imply its endorsement, recommendation, or favoring by the United States Government or the University of California. The views and opinions of authors expressed herein do not necessarily state or reflect those of the United States Government or the University of California, and shall not be used for advertising or product endorsement purposes.

This work was performed under the auspices of the U. S. Department of Energy by the University of California, Lawrence Livermore National Laboratory under Contract No. W-7405-Eng-48. 
UCRL-TR-231680

\section{Technical Basis Document}

\section{Estimation of Radiation Doses in the Marshall Islands Based on Whole Body Counting of Cesium-137 ( $\left.{ }^{137} \mathrm{Cs}\right)$ and Plutonium Urinalysis}

\section{J.I. Daniels, D.P. Hickman, S.R. Kehl, and T.F. Hamilton}

Marshall Islands Program

Lawrence Livermore National Laboratory

Livermore CA, 94551-0808

September 2007 



\section{Table of Contents}

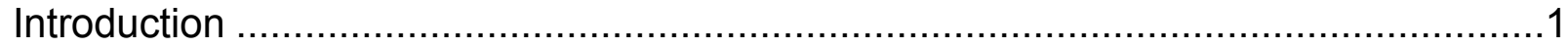

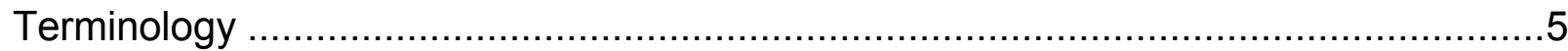

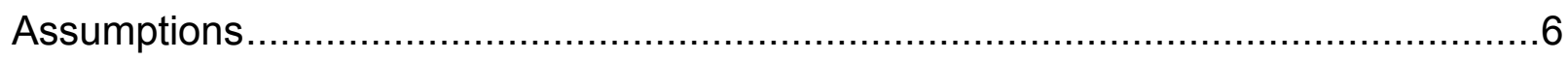

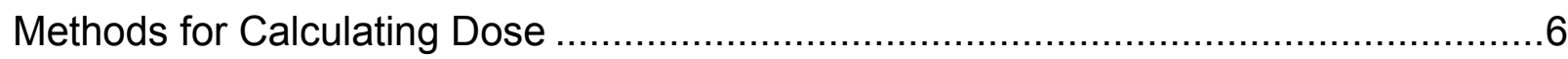

Equations for Determining an Age-Dependent, CEDE for ${ }^{137} \mathrm{Cs}$ from Reported Measurement Value(s) for a Calendar Year.....................................................9

Equations for Determining an Age-Dependent CEDE for ${ }^{239+240 P u}$ from Reported Measurement Values(s) for Calendar Year.

Procedures for Estimating Age-Dependent, Calendar Year Total Effective

Dose Equivalent (TEDE) from Radionuclide-Specific, Age-Dependent $\operatorname{CEDE}(\mathrm{s})$.

Interpreting Results from Comparison of Calendar Year Total TEDEage group to 15mrem y ${ }^{-1}$ TEDE Adopted by 1998 Nuclear Claims Tribunal Decision .......................13

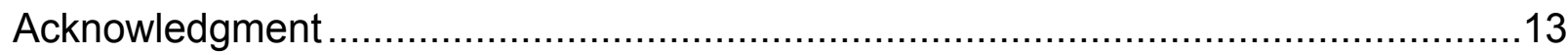

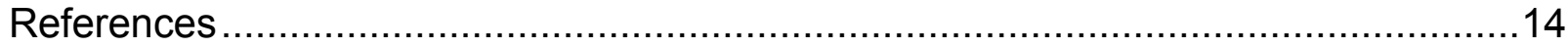

Appendix A: Derivation of Age-Dependent, Whole-Body Effective Dose Equivalent (EDE) Conversion Factors for ${ }^{137} \mathrm{Cs}$ and ${ }^{239+240 \mathrm{Pu}}$..............................................

Appendix B: Illustrative Sample Calculations for Hypothetical Measurements

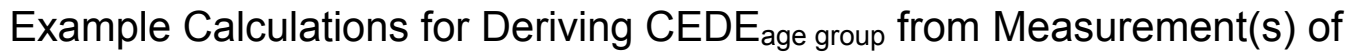
${ }^{137}$ Cs Activity by Whole-Body Counting

Example Calculations for Deriving CEDE age group from Measurement(s) of ${ }^{239+240} \mathrm{Pu}$ Activity Excreted in a 24-h Urine Void

Appendix C: Marshall Islands Dosimetry for Plutonium Isotopes in Urine for Calendar Years 1998 through 2004

Terminology $\mathrm{C}-2$

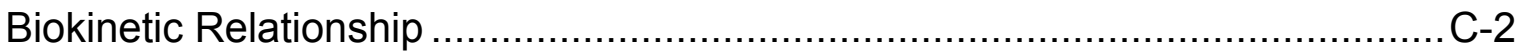

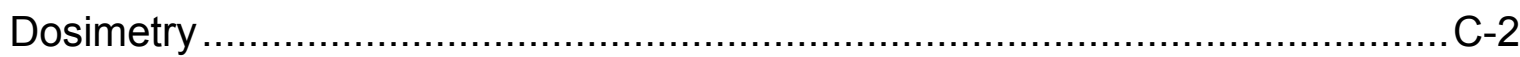

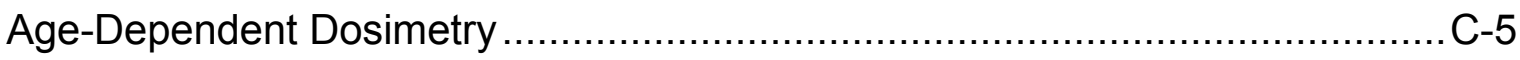




\section{List of Tables}

Table 1. Dose conversion factors (DCFs) applicable to ${ }^{137} \mathrm{Cs}$ and expressed as the age-dependent, whole-body effective dose equivalent (EDE) per unit nuclear transformation $(\mathrm{t})$.

Table 2. Age dependent Conversion Factor (CFCEDE) representing the agedependent, whole-body, (50-y) committed effective dose equivalent (CEDE) per total amount of $239+240 \mathrm{Pu}$ activity excreted during the year $\left(\mu \mathrm{Bq} \mathrm{y}^{-1}\right)$.

Table A-1. Derivation of ${ }^{137} \mathrm{Cs}$ whole-body effective dose equivalent (EDE) applicable to adult male.

Table A-2. Derivation of ${ }^{137} \mathrm{Cs}$ whole-body effective dose equivalent (EDE) applicable to adult female.

Table A-3. Derivation of ${ }^{137} \mathrm{Cs}$ whole-body effective dose equivalent (EDE) applicable to $15( \pm 3)$-y old (teenager).

Table A-4. Derivation of ${ }^{137} \mathrm{Cs}$ whole-body effective dose equivalent (EDE) applicable to $10( \pm 3)$-y old (pre-teenager) .

Table A-5. Derivation of ${ }^{137} \mathrm{Cs}$ whole-body effective dose equivalent (EDE) applicable to $5( \pm 3)$-y old (child)

Table A-6. Age-dependent organ mass (g), and ratio of adult to age-group organ masses (dimensionless)

Table A-7. Derivation of $239+240$ Pu whole-body committed effective dose equivalent conversion factor (CF CEDE) applicable to adult (>17 y)

Table A-8. Derivation of $239+240 \mathrm{Pu}$ whole-body committed effective dose equivalent conversion factor ( $\left.\mathrm{CF}_{\mathrm{CEDE}}\right)$ applicable to teenager (12 to $\left.17 \mathrm{y}\right)$

Table A-9. Derivation of $239+240 \mathrm{Pu}$ whole-body committed effective dose equivalent conversion factor ( $\left.\mathrm{CF}_{\mathrm{CEDE}}\right)$ applicable to pre-teenager (7 to $12 \mathrm{y}$ )

Table A-10. Derivation of $239+240 \mathrm{Pu}$ whole-body committed effective dose equivalent conversion factor $\left(\mathrm{CF}_{\mathrm{CEDE}}\right)$ applicable to child (2 to $\left.7 \mathrm{y}\right)$

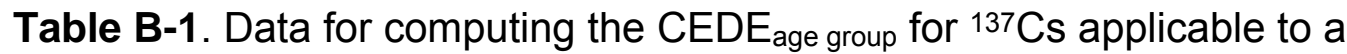
hypothetical human volunteer based on measurement(s) of ${ }^{137} \mathrm{Cs}$ activity by whole-body counting.

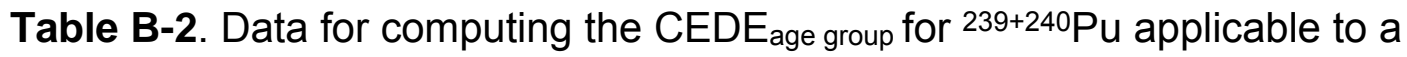
hypothetical human volunteer based on measurement(s) of ${ }^{239+240} \mathrm{Pu}$ activity excreted in a 24-h urine void.

Table C-1. ICRP specific effective energy (SEE) and weighting factors used for Marshall Islands Pu dosimetry prior to 2005

Table C-2. Lists of adult to age-group of interest organ-mass ratios used to SEE adjustment factors for age-dependent dose calculations 


\section{List of Figures}

Figure 1a. Relationship between absorbed dose from ${ }^{137} \mathrm{Cs}$ and corresponding residual burden of ${ }^{137} \mathrm{Cs}$ over time following an initial unit uptake

Figure 1b. Relationship between absorbed dose from ${ }^{239+240} \mathrm{Pu}$ and the residual burden of plutonium with time following an initial unit uptake

Figure 2. Biokinetic model for plutonium adapted from Fig. 9 (p. 17) in ICRP 78 (1998); adopted in ICRP 67 (1994).

Figure C-1. Equilibrium assumptions for plutonium dosimetry using only urinary excretion data. C-3 



\section{INTRODUCTION}

Under the auspices of the U.S. Department of Energy (USDOE), researchers from the Lawrence Livermore National Laboratory (LLNL) have recently implemented a series of initiatives to address long-term radiological surveillance needs at former nuclear test sites in the Republic of the Marshall Islands (RMI). The aim of this radiological surveillance monitoring program (RSMP) is to provide timely radiation protection for individuals in the Marshall Islands with respect to two of the most important internally deposited fallout radionuclides-cesium-137 $\left({ }^{137} \mathrm{Cs}\right)$ and long-lived isotopes 239 and 240 of plutonium $\left({ }^{239+240 \mathrm{Pu})}{ }^{*}\right.$ (Robison et al., 1997 and references therein). Therefore, whole-body counting for ${ }^{137} \mathrm{Cs}$ and a sensitive bioassay for the presence of ${ }^{239+240} \mathrm{Pu}$ excreted in urine were adopted as the two most applicable in vivo analytical methods to assess radiation doses for individuals in the RMI from internally deposited fallout radionuclides (see Hamilton et al., 2006a-c; Bell et al., 2002). Through 2005, the USDOE has established three permanent whole-body counting facilities in the Marshall Islands: the Enewetak Radiological Laboratory on Enewetak Atoll, the Utrōk Whole-Body Counting Facility on Majuro Atoll, and the Rongelap Whole-Body Counting Facility on Rongelap Atoll.

These whole-body counting facilities are operated and maintained by trained Marshallese technicians. Scientists from LLNL provide the technical support and training necessary for maintaining quality assurance for data acquisition and dose reporting. This technical basis document summarizes the methodologies used to calculate the annual total effective dose equivalent (TEDE; or dose for the calendar year of measurement) based on whole-body counting of internally deposited ${ }^{137} \mathrm{Cs}$ and the measurement of $239+240 \mathrm{Pu}$ excreted in urine.

Whole-body counting provides a direct measure of the total amount (or burden) of ${ }^{137} \mathrm{Cs}$ present in the human body at the time of measurement. The amount of ${ }^{137} \mathrm{Cs}$ detected is often reported in activity units of kilo-Becquerel $(\mathrm{kBq})$, where $1 \mathrm{kBq}$ equals $1000 \mathrm{~Bq}$ and $1 \mathrm{~Bq}=1$ nuclear transformation per second $\left(\mathrm{t} \mathrm{s}^{-1}\right)$. [However, in the United States the curie $(\mathrm{Ci})$ continues to be used as the unit of radioactivity; where $1 \mathrm{Ci}=$ $3.7 \times 10^{10} \mathrm{~Bq}$.] The detection of ${ }^{239} \mathrm{Pu}$ and ${ }^{240} \mathrm{Pu}$ in bioassay (urine) samples indicates the presence of internally deposited (systemic) plutonium in the body. Urine samples that are collected in the Marshall Islands from volunteers participating in the RSMP are transported to LLNL, where measurements for ${ }^{239+240} \mathrm{Pu}$ are performed using a state-ofthe-art technology based on Accelerator Mass Spectrometry (AMS) (Hamilton et al., 2004, 2007; Brown et al., 2004).

\footnotetext{
* The isotopic composition of plutonium in the terrestrial environment varies depending on the source. For example, high-yield atmospheric nuclear tests conducted in the Marshall Islands produced atom ratios of ${ }^{240} \mathrm{Pu}$ to ${ }^{239} \mathrm{Pu}$ in fallout of about 0.30 to 0.35 (whereas unfissioned, weapons-grade nuclear fuel contains a ${ }^{240} \mathrm{Pu}$ to ${ }^{239} \mathrm{Pu}$ atom ratio of approximately 0.05 ).
} 
The urinary excretion of plutonium by RSMP volunteers is usually described in activity units, expressed as micro-Becquerel $(\mu \mathrm{Bq})$ of ${ }^{239+240} \mathrm{Pu}$ (i.e., representing the sum of the ${ }^{239} \mathrm{Pu}$ and ${ }^{240} \mathrm{Pu}$ activity) excreted (lost) per day $\left(\mathrm{d}^{-1}\right)$, where $1 \mu \mathrm{Bq} \mathrm{d}^{-1}=$ $10^{-6} \mathrm{~Bq} \mathrm{~d}^{-1}$ and $1 \mathrm{~Bq}=1 \mathrm{t} \mathrm{s}^{-1}$. The systemic burden of plutonium is then estimated from biokinetic relationships as described by the International Commission on Radiological Protection (e.g., see ICRP, 1990).

In general, nuclear transformations are accompanied by the emission of energy and/or particles in the form of gamma rays $(\gamma)$, beta particles $(\beta)$, and/or alpha particles $(\alpha)$. Tissues in the human body may adsorb these emissions, where there is a potential for any deposited energy to cause biological damage. The general term used to quantify the extent of any radiation exposure is referred to as the dose. The equivalent dose is defined by the average absorbed dose in an organ or tissue weighted by the average quality factor for the type and energy of the emission causing the dose. The effective dose equivalent (EDE; as applied to the whole body), is the sum of the average dose equivalent for each tissue weighted by each applicable tissue-specific weighing factor (which equates to the sensitivity of that tissue to damage by the equivalent radiation dose it receives). The $\mathrm{SI}^{\dagger}$ unit of effective dose equivalent is the joule per kilogram ( $\mathrm{J}$ $\mathrm{kg}^{-1}$ ), named the Sievert (Sv). The unit often used by federal and state agencies in the United States to describe EDE continues to be the more historical radiation equivalent man (rem); where 1 rem $=0.01 \mathrm{~Sv}$.

Based on the measurements of the internally deposited ${ }^{137} \mathrm{Cs}$ and/or the urinary excretion of plutonium, an estimate can be derived for these radionuclides of the annual number of nuclear transformations $\left(t \mathrm{y}^{-1}\right)$ that occurred in the body during the year in which measurement was performed. For both radionuclides, this result is the time integral of activity in the body of an individual normalized over a one-year measurement period, and these radionuclide-specific transformations yield the emissions that are responsible for the radionuclide-specific EDE committed for that year.

In addition to the nuclear transformations that produce the committed EDE for the year of measurement of a radionuclide in the body, additional transformations may occur in the future due to the presence of residual radioactive material being present in the body at the end of the measurement year. Accordingly, the additional EDE committed to the individual for the future by such residual material will be a function of the biological half-time ${ }^{\ddagger}$ of the specific radioactive element(s), and the number of

\footnotetext{
† Systéme International [d'Unités] (International System [of Units]), where the United States has not totally implemented the Systéme International d'Unités, especially with respect to units of radioactivity (as discussed earlier) and radiation dose.

‡ For the purposes of this discussion, the term biological half-time is to be considered synonymous with the term biological half-life or the time in which one half the material is removed from a biological compartment (or system) in the absence of additional input to that compartment (or system).
} 
transformations associated with the presence of such residual radioactivity evaluated for up to $50 \mathrm{y}$ in the future [which the United States Environmental Protection Agency (USEPA) defines for members of the public as a conservative maximum period] in order to estimate the expected EDE commitment.

It is considered appropriate and conforming with the national and international recommendations of the USEPA and the ICRP to assign to the year of its measurement the EDE commitment that is estimated to occur up to $50 \mathrm{y}$ in the future for a radionuclide. Thus, the number of nuclear transformations for a particular radionuclide estimated to occur in the body of an individual during the measurement year is summed with those estimated to occur for up to $50 \mathrm{y}$ in the future or until the radionuclide producing them has been eliminated completely from the body. The corresponding radionuclide-specific EDE that is committed from the sum of these transformations equals the committed effective dose equivalent (CEDE) for the individual from that radionuclide.

For example, Figures $1 \mathrm{a}$ and $1 \mathrm{~b}$ illustrate the accumulation of absorbed dose and the residual burden of ${ }^{137} \mathrm{Cs}$ and ${ }^{239+240} \mathrm{Pu}$, respectively, as a function of time (in years) after a unit uptake. In the case of ${ }^{137} \mathrm{Cs}$ (Fig. 1a), based on its biokinetics for distribution and retention (see ICRP, 1990), the integrated total absorbed dose from an initial acute uptake occurs about 2 y into the future. In this case, the integrated dose over this 2-y period provides a reasonable estimate of the CEDE for the year of measurement. In comparison, plutonium has a biological half-life of approximately 20 y to 50 y (see ICRP 1990) and so its elimination is not likely to occur completely over a typical human lifespan.

The total calendar year dose or TEDE (total effective dose equivalent) for a specified age group represents the summation of radionuclide-specific, age-dependent, CEDEs for all monitored radionuclides. Under the Marshall Islands RSMP, only the

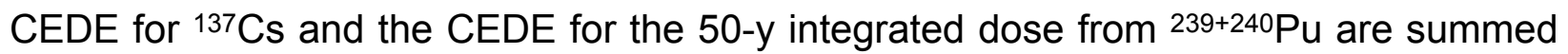
to represent the annual TEDE for the year in which they are measured as these two radionuclides represent the two most significant contributors to internal radiation dose for exposed members of the public in the Marshall Islands.

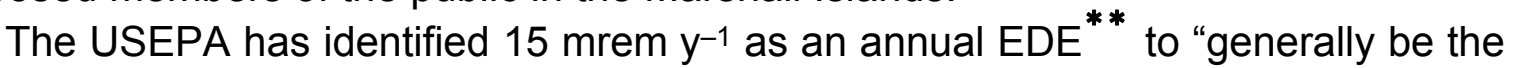
maximum dose limit for humans" (with respect to the combination of external dose and CEDE from internally deposited radionuclides for up to 50 years into the future assigned to the year of measurement), and applicable as criteria and guidance (but not

\footnotetext{
** The SI unit used by the international community to represent this effective dose equivalent (EDE) is 0.15 millisievert (mSv), where $1 \mathrm{mSv}=100 \mathrm{mrem}$. The annual EDE for internally deposited radionuclides is interpreted as the committed effective dose equivalent (CEDE) for up to $50 \mathrm{y}$ into the future assigned to the year of measurement.
} 

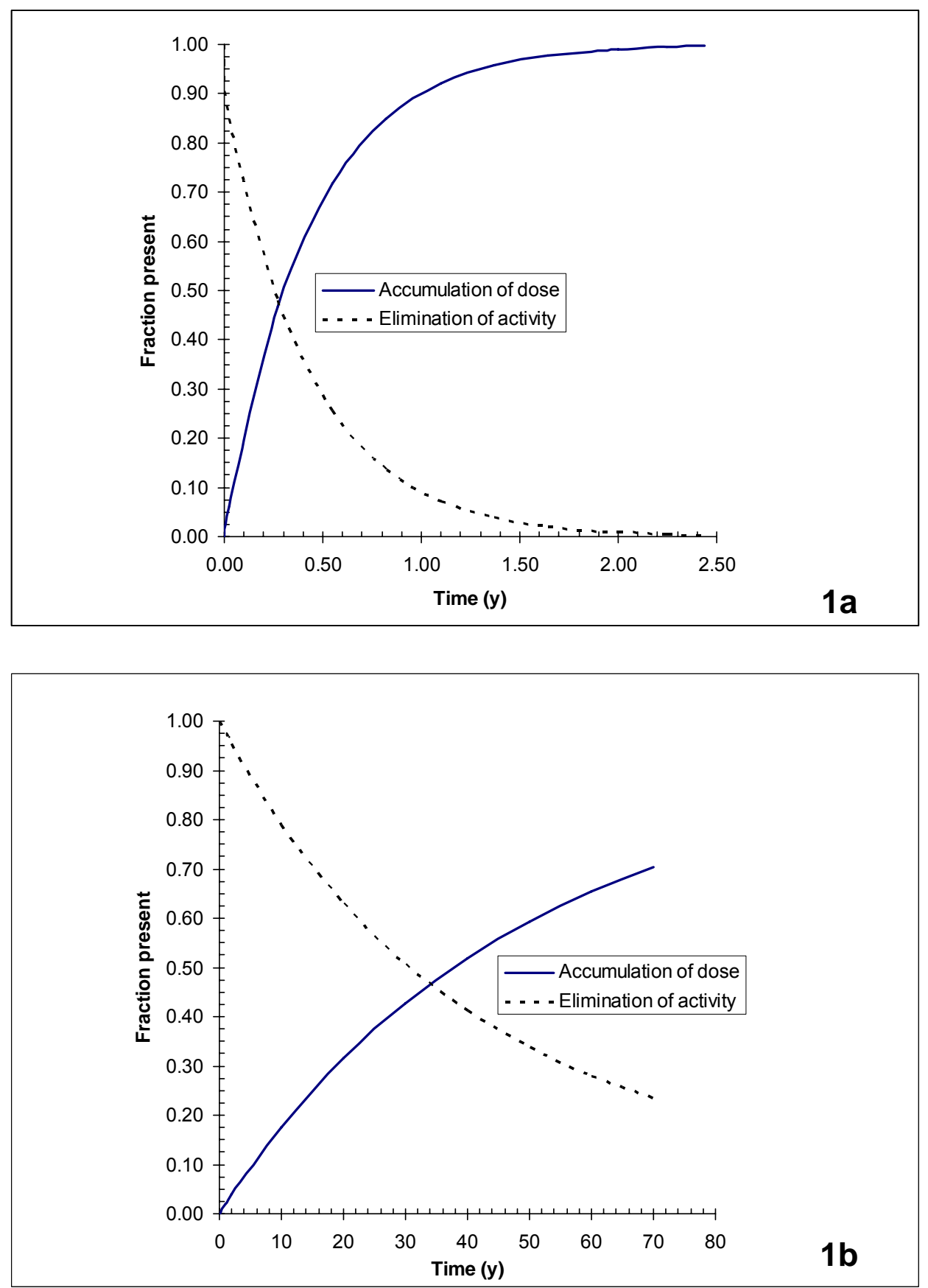

Figure $1(a$ and $b)$. Figure 1a illustrates the relationship between absorbed dose from ${ }^{137} \mathrm{Cs}$ and the corresponding residual burden of ${ }^{137} \mathrm{Cs}$ over time following an initial unit uptake; and Figure $1 \mathrm{~b}$ shows the relationship between absorbed dose from ${ }^{239+240} \mathrm{Pu}$ and the residual burden of plutonium with time following an initial unit uptake (after ICRP, 1990). 
as a dose-based regulation) to control exposures to residual radioactivity above background at a hazardous-waste site. This guidance equates to an average excess lifetime cancer morbidity (incidence) risk of about $3 \times 10^{-4}$ (appropriate at the time the rationale was explained), based on a $30-y$ period of exposure (the expected lifetime exposure from analysis of population mobility data for the continental U.S.) or a total lifetime dose of 450 mrem (i.e., $30 \mathrm{y} \times 15 \mathrm{mrem} \mathrm{y}^{-1}$ ) (see ISCORS, 2002; Luftig and Weinstock, 1997; and USEPA, 1994). In December 1998, the Nuclear Claims Tribunal of the Republic of the Marshall Islands (NCT/RMI) issued a Memorandum of Decision and Order that concludes by adopting the USEPA guidance of $15 \mathrm{mrem} \mathrm{y}^{-1}$ EDE as a standard that would "... provide the basis on which evidence will be presented to the Tribunal for it to determine the need for and cost of radiological rehabilitation of any atolls where such action may be warranted" (NTC/RMI, 2004).

\section{TERMINOLOGY}

It is very important to recognize the subtle distinction in terminology between the annual TEDE (or total calendar-year dose) based on whole-body counting for ${ }^{137} \mathrm{Cs}$ and bioassay measurements of $239+240 \mathrm{Pu}$ excreted in urine, and the CEDE (committed effective dose equivalent) that is used specifically in the description of the maximum annual dose limit of $15 \mathrm{mrem} \mathrm{y}^{-1}$ (that includes both external and internal dose integrated over $50 \mathrm{y}$ ). The CEDE calculation assumes that the uptake of ${ }^{239} \mathrm{Pu}$ and ${ }^{240} \mathrm{Pu}$ is continuous and chronic, not only for the calendar year of measurement but also for $50 \mathrm{y}$ into the future. This steady-state assumption implies that the amount of plutonium in the body of people will not change over time. Using steady state conditions is conservative, that is to say a dose maximizing assumption. Nevertheless, the radiological surveillance-monitoring program requires confirmation of elevated levels of urinary excretion of plutonium because measured levels may be attributed potentially to more acute incremental intake scenarios. In this latter case, a more thorough investigation would be conducted to determine the computation of dose more accurately.

Additionally, the CEDE calculation for individuals participating in the RSMP in the $\mathrm{RMI}$ ignores contributions from external radiation exposure as well as internal doses from intakes of fallout radionuclides other than ${ }^{137} \mathrm{Cs}$ and ${ }^{239} \mathrm{Pu}$ and ${ }^{240} \mathrm{Pu}$, such as strontium-90 ( $\left.{ }^{90} \mathrm{Sr}\right)$. If such other fallout radionuclides are consumed, the total calendar year dose to individuals from exposure to residual fallout contamination in the Marshall Islands may be higher than that calculated from only the whole-body counting for ${ }^{137 \mathrm{Cs}}$ and the bioassay for ${ }^{239+240} \mathrm{Pu}$ in urine.

The TEDE being assessed for the volunteers participating in the radiological surveillance monitoring program in the RMI is computed in units of Sv $\mathrm{y}^{-1}$ and rem $\mathrm{y}^{-1}$, and equates to the potential internal biological dose that can occur as a result of absorption in tissues and organs of the emissions of radiations produced by the 


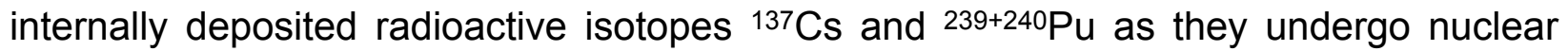
transformations during their decay. When only one radionuclide is measured, the TEDE for the calendar year and the CEDE for the specific radionuclide for that calendar year are identical. When more than one radionuclide is measured, the TEDE is the sum of CEDEs corresponding to each of the radionuclides for the calendar year of measurement. The annual TEDE based on whole-body counting of ${ }^{137} \mathrm{Cs}$ and the bioassay for ${ }^{239+240} \mathrm{Pu}$ in urine is to be compared to the USEPA recommended

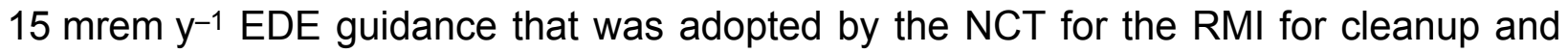
rehabilitation of sites contaminated by radioactive fallout. Furthermore, because of the long biological half-time of plutonium in the body, any measurement of ${ }^{239+240} \mathrm{Pu}$ in urine that is elevated and yields a dose approaching the $15 \mathrm{mrem} \mathrm{y}^{-1}$ may be attributed to a recent acute-incremental intake scenario, and in such cases a more thorough investigation would be conducted to determine the possible origin of such dose and compute it with higher fidelity.

\section{ASSUMPTIONS}

The mathematical procedures employed to convert whole-body counts of ${ }^{137} \mathrm{Cs}$ and in-vitro bioassay measurements of plutonium isotopes in 24-h urine samples to a CEDE are based on the following assumptions. First, uptake of these radionuclides is considered to be continuous and chronic throughout the year of measurement and, after uptake, these radionuclides are distributed across physiological compartments of the human body according to model assumptions described by the ICRP (1980; 1990). Additionally, the dominant exposure pathways for ${ }^{137} \mathrm{Cs}$ and plutonium isotopes are assumed to be ingestion and inhalation, respectively. Furthermore, ${ }^{240} \mathrm{Pu}$ will always be

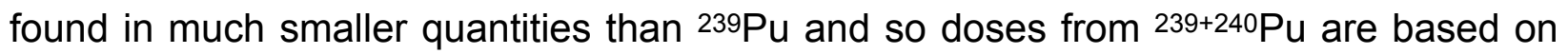
absolute measurements of ${ }^{239} \mathrm{Pu}$ and ${ }^{240} \mathrm{Pu}$, even if the only valid measurement of excreted plutonium was for ${ }^{239} \mathrm{Pu}$ alone. Finally, the general approach for assessing dose from exposure measurements is considered consistent with methods described by the ICRP for members of the public in its publications numbers 30 and its supplement to Part 1; 56; 67; 69; 71; and 72 (ICRP, 1979 and 1980; 1990; 1994; 1995; 1996a,b).

\section{METHODS FOR CALCULATING DOSE}

For volunteers participating in this radiological surveillance monitoring program, both the whole-body counting of ${ }^{137} \mathrm{Cs}$ and the bioassay measurements of plutonium in urine are used to estimate the total activity $(\mathrm{Bq})$ of these radionuclides in the body at the time of measurement. The respective measurement(s) of activity for either ${ }^{137} \mathrm{Cs}$ or for ${ }^{239+240} \mathrm{Pu}$ are then integrated over the entire calendar year to yield an estimate of the total number of nuclear transformations for that year $\left(\mathrm{t} \mathrm{y}^{-1}\right) .{ }^{137} \mathrm{Cs}$ is considered to be distributed in the human body into fractions of 0.1 and 0.9 to each of two compartments, with each fraction having a retention half life of 2 and 110 days, respectively (see ICRP, 
1980). For ${ }^{137} \mathrm{Cs}$, the transformations in a one year period are combined with an estimate of the number of transformations that occur from the end of the measurement period until 50 years into the future (in seconds) by which time this remaining ${ }^{137} \mathrm{Cs}$ activity will be eliminated completely from the body (see Fig. 1a), assuming the long term biological half-time for ${ }^{137} \mathrm{Cs}$ is 110 days. This sum of nuclear transformations can then be multiplied by the respective age-dependent, whole-body committed effective dose equivalent (CEDE) conversion factor (e.g., Sv t ${ }^{-1}$ ) to obtain the CEDE (for ${ }^{137} \mathrm{Cs}$ ) during the year of measurement for the individual.

A similar, but not identical, procedure is used to generate a CEDE for ${ }^{239+240} \mathrm{Pu}$ for the different age group categories. Again, this CEDE will represent dose commitment for the year in which the exposure measurement is made and for $50 \mathrm{y}$ into the future assigned to that year of measurement. In this procedure measurement(s) of daily excretion rate(s) integrated over the entire calendar year estimate the total $239+240 \mathrm{Pu}$ activity $(\mu \mathrm{Bq})$ excreted for that calendar year for an individual. This value is then multiplied by a factor that converts this annual excreted ${ }^{239+240} \mathrm{Pu}$ activity to a whole-body 50-y CEDE (assigned to the year of measurement).

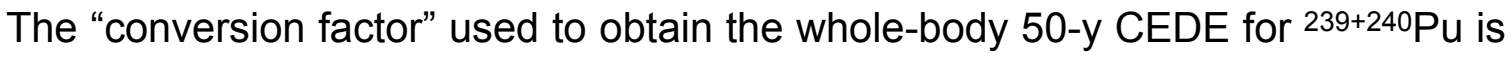
the sum of the conversion factors used to represent each of the organ-specific 50-y CEDEs per activity unit excreted in urine annually (i.e., $\Sigma \mathrm{CF}_{\mathrm{CEDE}}$ ). Each organ-specific conversion factor is the 50-y CEDE in that organ per activity unit excreted in urine annually (e.g., Sv [for $50 \mathrm{y}$ ] $\mu \mathrm{Bq}^{-1}$ [excreted annually]) and is obtained from the biokinetic modeling of ${ }^{239+240} \mathrm{Pu}$ activity $(\mathrm{Bq})$ in the organ of interest per activity unit excreted in urine daily $\left(\mu \mathrm{Bq} \mathrm{d} \mathrm{d}^{-1}\right)$. This biokinetic modeling is performed using the IMBA Expert $^{\mathrm{TM}}$ USDOE-Edition (Phase II) software obtained from ACJ \& Associates, Inc. (2004). The software is a collection of "Integrated Modules for Bioassay Analysis" (IMBA) and features use of the biokinetic model for the actinide elements (thorium, neptunium, plutonium, americium, and curium), adopted in ICRP Publication 67 (ICRP, 1994), along with the values for the transfer rates between its compartments currently recommended in ICRP Publication 78 (ICRP, 1998). Figure 2 [adapted from Fig. 9 (p. 17 ) in ICRP Publication 78 (ICRP, 1998)] shows the biokinetic model for plutonium.

The bioassay calculation from IMBA yielding the organ-specific activity of

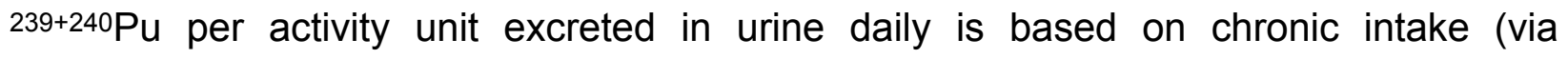
inhalation) of insoluble plutonium under equilibrium conditions. Accordingly, a urine-bioassay measurement rate for ${ }^{239+240} \mathrm{Pu}$ activity equal to $1 \mu \mathrm{Bq} \mathrm{d}^{-1}$ is set in IMBA. This daily excretion rate of ${ }^{239+240} \mathrm{Pu}$ activity is then used by IMBA to infer a corresponding inhalation intake rate of $5.4 \mu \mathrm{Bq} \mathrm{d}^{-1}$ per $1 \mu \mathrm{Bq} \mathrm{d}^{-1}$ excreted of $239+240 \mathrm{Pu}$ activity. 


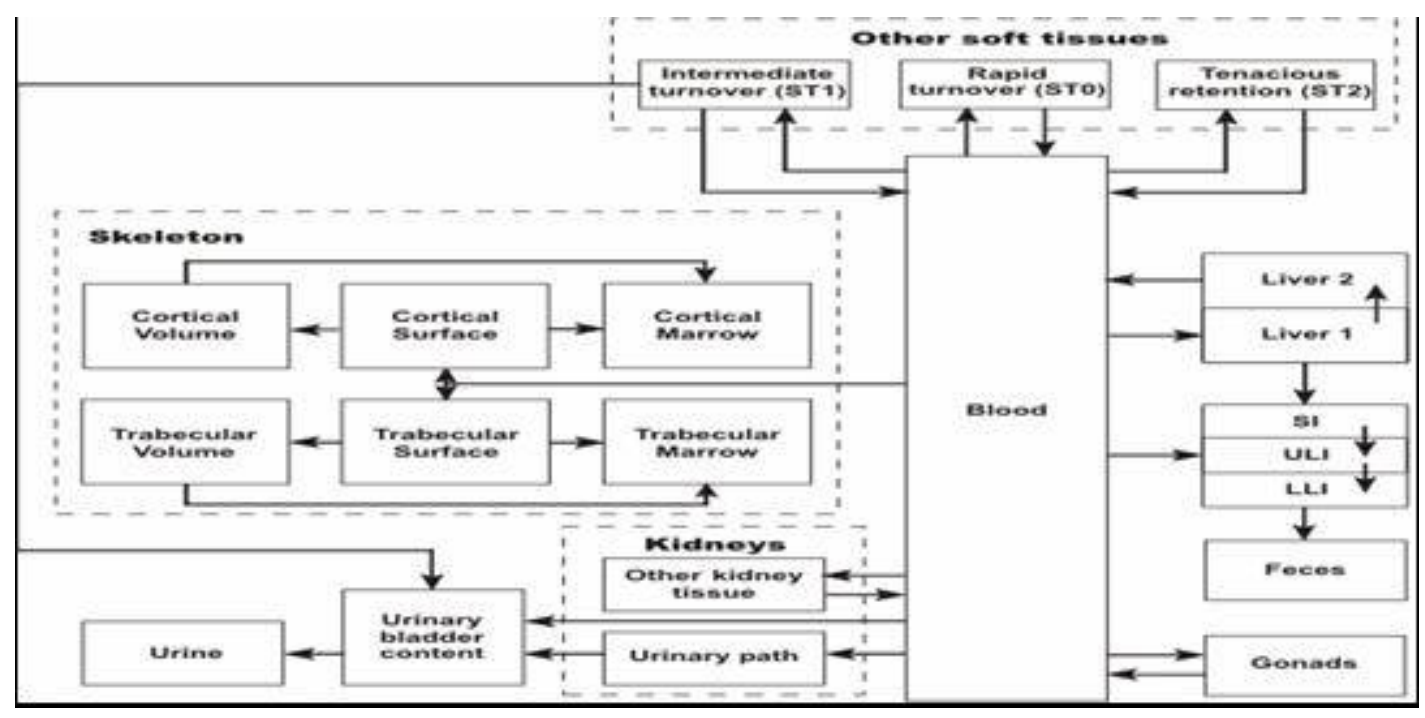

Figure 2. Biokinetic model for plutonium adapted from Fig. 9 (p. 17) in ICRP 78 (1998); adopted in ICRP 67 (1994).

The IMBA derived intake-rate value then serves as the basis for IMBA to also predict corresponding activities of ${ }^{239+240} \mathrm{Pu}$ in the biological compartments (organs) of greatest interest [i.e., lungs, liver, cortical (bone) surface, trabecular (bone) surface, upper large intestine, and lower large intestine]. Additionally, each organ-specific $C_{\text {CEDE }}$

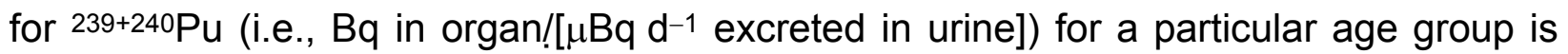
computed as the product of the following terms: IMBA generated equilibrium activity of ${ }^{239+240} \mathrm{Pu}$ in an organ of interest $(\mathrm{Bq})$ per ${ }^{239+240} \mathrm{Pu}$ activity unit excreted in urine daily (1 $\left.\mu \mathrm{Bq} \mathrm{d} \mathrm{d}^{-1}\right)$; a factor for converting day to seconds $\left(8.64 \times 10^{4} \mathrm{~s} \mathrm{~d}^{-1}\right)$; the duration of committed dose (50 y); the specific effective energy (SEE) as the energy absorbed per unit mass of organ tissue per transformation for the alpha particles in each relevant adult organ $[\mathrm{MeV} /(\mathrm{g} \times \mathrm{t})]$; factors for converting SEE to Sv t-1 $\left[1.6 \times 10^{-13} \mathrm{~J} \mathrm{MeV}^{-1} \times 1 \times\right.$ $\left.10^{3} \mathrm{~g} \mathrm{~kg}^{-1} \times 1 \mathrm{~Sv} /\left(\mathrm{J} \mathrm{kg}^{-1}\right)=1.6 \times 10^{-10}(\mathrm{~Sv} \times \mathrm{g}) \mathrm{MeV}^{-1}\right]$; organ-specific tissue weighting factor (dimensionless), representing relative susceptibility of the organ to stochastic effects; and adult age-group to the age-group of interest organ-mass ratio (dimensionless).

Because alpha particles dominate the energy deposition (and dose) per unit organ mass and have short range, it is assumed that all energy deposition from

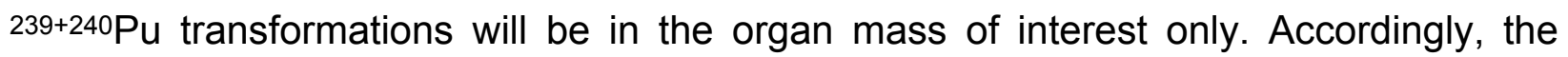
adult age-group to age-group of interest organ mass is used as a simple correction factor to adjust the SEE value in an organ of an adult to one that is appropriate for a younger age group of interest. This ratio will always be greater than one because for all 
organs, adult organ mass is greater than that for the same organ in younger age groups.

The data used to derive age-dependent, whole-body committed effective dose equivalents (CEDE) for the year of intake are tabulated in Appendix $A$. Specific illustrative examples of the application of the equations appears in Appendix $B$. Appendix C provides an earlier (1998-2004) and less precise applied method for evaluating the dose from ${ }^{239+240} \mathrm{Pu}$ based on urinary excretion measurements.

\section{Equations for Determining an Age-Dependent, CEDE for ${ }^{137}$ Cs from Reported Measurement Value(s) for a Calendar Year}

For ${ }^{137} \mathrm{Cs}$, the number of transformations per year in the body $\left(A_{\mathrm{t}} ; \mathrm{t} \mathrm{y}^{-1}\right)$ predicted to occur during the year of measurement are determined using Equation 1:

$$
A_{t}=\left[m_{i} t_{i}+m_{N}\left(365-t_{N}\right)+\sum_{i=1}^{N-1} \frac{\left(m_{i}+m_{i+1}\right)}{2}\left(t_{i+1}-t_{i}\right)\right] \times u_{c f}, \text { where }
$$

$m_{i}=i^{\text {th }}$ measurement of whole-body activity $(\mathrm{kBq})$ in a series from 1 up to $N$ measurements taken during the calendar year (e.g., $i=1,2, \ldots N)$, and where $N-1$ is equal to zero, the summation term defaults to a value of zero;

$t_{i}=$ calendar day of $i^{\text {th }}$ measurement (e.g., 1, 2, 150, up to 365; or 366 in a leap year; and

$u_{c f}=$ unit conversion factor of $8.64 \times 10^{7}$ [representing the product of $1000 \mathrm{t} \mathrm{s}^{-1}$ (or Bq) $/ \mathrm{kBq}^{-1}$ and $24 \mathrm{~h} \mathrm{~d}^{-1} \times 3600 \mathrm{~s} \mathrm{~h}^{-1}$ ].

The additional committed transformations in the body from ${ }^{137} \mathrm{Cs}$ assigned to the calendar of measurement $\left(A_{c} ; \mathrm{t} \mathrm{y}^{-1}\right)$ is obtained using Equation 2:

$$
A_{c}=m_{N} \int_{t=2 y}^{50 y}\left(0.1 e^{-\left(\frac{\ln (2)}{2}+\frac{\ln (2)}{1.1 \times 10^{4}}\right) t}+0.9 e^{-\left(\frac{\ln (2)}{110}+\frac{\ln (2)}{1.1 \times 10^{4}}\right) t}\right) \times u_{c f}, \text { where }
$$

$m_{N}=N^{\text {th }}$ measurement of whole-body activity $(\mathrm{kBq})$ in a series of up to $N$ measurements taken during the calendar year (of measurement; and

$u_{c f}=$ unit conversion factor of $8.64 \times 10^{7}$ [representing the product of $1000 \mathrm{t} / \mathrm{s}$ (or $\mathrm{Bq}) / \mathrm{kBq}$ and $24 \mathrm{~h} / \mathrm{d} \times 3600 \mathrm{~s} / \mathrm{h}]$.

Because ${ }^{137} \mathrm{Cs}$ is rapidly removed from the body and will be eliminated well before the 50-y duration of the integral (see Fig. 1a), Eq. 2 can be approximated by the analytical expression appearing in Eq. 3, 


$$
A_{c}=m_{N}\left[\frac{0.1}{\ln (2)} \times 2 \mathrm{~d}+\frac{0.9}{\ln (2)} \times 110 \mathrm{~d}\right] \times 8.64 \times 10^{7}, \text { where }
$$

the values of 0.1 and 0.9 (in both Eqs. 2 and 3) represent the fractions of cesium that are considered to be distributed into the two biokinetic compartments described by ICRP Figs 1a-1b (ICRP, 1980) that possess 2-d and 110-d retention half lives, respectively.

The total number of transformations attributed to the year of measurement $\left(A_{t}\right)$ is then summed with the transformations $\left(A_{c}\right)$ committed into the future that are estimated from the last measurement $\left(m_{N}\right)$ and assigned to the year of measurement. This summation of total activity $\left(A_{T}\right)$ is described by Eq. 4 :

$$
A_{T}=A_{t}+A_{c} \text {, applicable to }{ }^{137} \mathrm{Cs} \text {. }
$$

An age-dependent, CEDE for ${ }^{137} \mathrm{Cs}$, expressed in units of Sv $\mathrm{y}^{-1}$ or rem $\mathrm{y}^{-1}$ (where $1 \mathrm{~Sv} \mathrm{y}^{-1}=10^{2} \mathrm{rem}^{-1}$ ) is then obtained using Eq. 5 as the product of the value of $\mathrm{A}_{T}$ and the appropriate age-specific, whole-body dose conversion factor (DCF) as found in Table 1.

Table 1. Dose conversion factors (DCFs) applicable to ${ }^{137} \mathrm{Cs}$ and expressed as the age-dependent, whole-body effective dose equivalent (EDE) per unit nuclear transformation $(\mathrm{t}){ }^{\mathrm{a}}$

\begin{tabular}{lcc}
\hline & \multicolumn{2}{c}{$\begin{array}{c}\text { Age-dependent, whole-body effective dose } \\
\text { equivalent (EDE) per unit nuclear transformation }\end{array}$} \\
\cline { 2 - 3 } \multicolumn{1}{c}{ Applicable age } & Sv t $^{\mathbf{- 1}}$ & rem t $^{\mathbf{b}}$ \\
\hline Adult male & $1.16 \times 10^{-15}$ & $1.16 \times 10^{-13}$ \\
Adult female & $1.39 \times 10^{-15}$ & $1.39 \times 10^{-13}$ \\
Teenager (12 to $18 \mathrm{y})$ & $1.41 \times 10^{-15}$ & $1.41 \times 10^{-13}$ \\
Adolescent $(7$ to $12 \mathrm{y})$ & $2.24 \times 10^{-15}$ & $2.24 \times 10^{-13}$ \\
Child $(\leq 7 \mathrm{y})$ & $3.58 \times 10^{-15}$ & $3.58 \times 10^{-13}$
\end{tabular}

a These DCFs include the products of age-dependent, specific effective energies (SEEs) computed using SEECAL software (Cristy and Eckerman, 1995) for ${ }^{137} \mathrm{Cs}$ in specific target organs, and corresponding organ-specific tissue weighting factors $\left(w_{t}\right)$ obtained from ICRP 56 (1990). See Tables A-1 to A-5 in Appendix $A$ for the data used to derive these DCFs for ${ }^{137} \mathrm{Cs}$.

b $1 \mathrm{~Sv} \mathrm{t}^{-1}=10^{2} \mathrm{rem} \mathrm{t}^{-1}$ or $10^{5} \mathrm{mrem} \mathrm{t}^{-1}$; because $1 \mathrm{rem} \mathrm{t}^{-1}=10^{3} \mathrm{mrem} \mathrm{t}^{-1}$. 
$\mathrm{CEDE}_{\text {age group }}=A_{T}\left(\right.$ for $\left.{ }^{137} \mathrm{Cs}\right) \times \mathrm{DCF}_{\text {age group }} ;$ where

Eq. 5

$\mathrm{DCF}_{\text {age group }}=$ effective dose equivalent $(E D E)$ per unit transformation (i.e., Sv t $\mathrm{t}^{-1}$ or rem $\mathrm{t}^{-1}$ ) found in Table 1.

The data supporting the derivation of the age-specific, whole-body EDEs per unit transformation appearing in Table 1 are tabulated in Tables A-1 through A-5 of Appendix A. Illustrative examples of the application of Equations 1 through 5 to hypothetical measurement data are presented in Appendix B.

\section{Equations for Determining an Age-Dependent CEDE for 239+240Pu from Reported Measurement Value(s) for a Calendar Year.}

Confirmed measurements of ${ }^{239} \mathrm{Pu}$ and ${ }^{240} \mathrm{Pu}$ by AMS in 24 -h urine voids (in units of $\mu \mathrm{Bq} \mathrm{d}^{-1}=1 \times 10^{-6} \mathrm{~Bq} \mathrm{~d}^{-1}$ ) are identified as the total activity excreted per day ( $\mu \mathrm{Bq} \mathrm{d} \mathrm{d}^{-}$

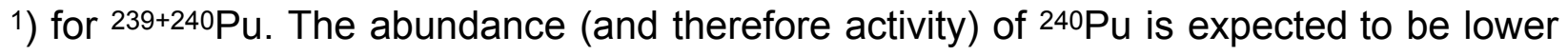

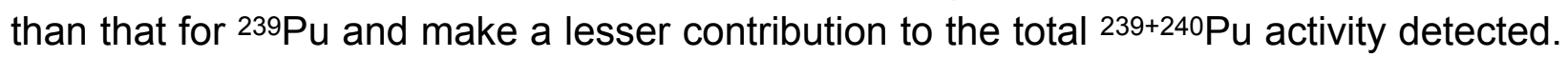
Accordingly, the age dependent CEDE derived from measurements of total $239+240 \mathrm{Pu}$ will be dominated by the presence of the more abundant ${ }^{239} \mathrm{Pu}$ but includes the contribution to dose from the activities of any valid measurements of $240 \mathrm{Pu}$. Under circumstances where only the AMS measurement for ${ }^{239} \mathrm{Pu}$ in a $24-\mathrm{h}$ urine void is considered valid and positive for a particular sample (i.e., ${ }^{240} \mathrm{Pu}$ is not detected), the total daily excretion rate for ${ }^{239} \mathrm{Pu}\left(\mu \mathrm{Bq} \mathrm{d} \mathrm{d}^{-1}\right)$ is considered to represent the total amount of plutonium activity excreted per day (i.e., $\mu \mathrm{Bq} \mathrm{d}^{-1}$ for ${ }^{239+240} \mathrm{Pu}$ ). In this case, only ${ }^{239} \mathrm{Pu}$ activity would actually contribute to the derived age dependent CEDE for ${ }^{239+240} \mathrm{Pu}$.

For ${ }^{239+240} \mathrm{Pu}$, the first step in determining the CEDE is to sum the daily excretion rate measurement $\left(\mathrm{Bq} \mathrm{d}^{-1}\right)$ for ${ }^{239} \mathrm{Pu}$ with that for ${ }^{240} \mathrm{Pu}$ obtained by $\mathrm{AMS}$ analysis of $24-\mathrm{h}$ urine void samples. Then an integrated excretion of ${ }^{239+240} \mathrm{Pu}$ activity (e.g., in $\mu \mathrm{Bq}$ ) for the calendar year $\left(A_{t}\right)$ is estimated based on the number of 24-h urine samples bioassays measured in that calendar year. This calculation is performed using Eq. 1 with measurements of $\mu \mathrm{Bq} \mathrm{d}^{-1}$ as input, where $A_{t}$ in this case is applicable to ${ }^{239+240} \mathrm{Pu}$ activity excreted for the entire calendar year and is in units of $\mu \mathrm{Bq} \mathrm{y}^{-1}$.

For example,

$$
\begin{aligned}
& A_{t}=\left\lfloor m_{i} t_{i}+m_{N}\left(365-t_{N}\right)+\sum_{i=1}^{N-1} \frac{\left(m_{i}+m_{i+1}\right)}{2}\left(t_{i+1}-t_{i}\right)\right\rfloor, \text { where } \quad \text { Eq. 1a } \\
& m_{i}=i^{\text {th }} \text { measurement of }{ }^{239+240} \mathrm{Pu} \text { activity }\left(\mu \mathrm{Bq} \mathrm{d} \mathrm{d}^{-1}\right) \text { in a series from } 1 \text { up to } N
\end{aligned}
$$




$$
\begin{aligned}
t_{i}= & \text { calendar day of } i^{\text {th }} \text { measurement (e.g., } 1,2, \ldots 150, \ldots \text { up to } 365 \mathrm{~d}^{-1} \text {; or } \\
& 366 \mathrm{~d}^{-1} \text { in a leap year). }
\end{aligned}
$$

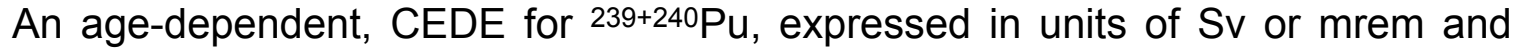
assigned to the year of measurement, is calculated in this case as the product of two terms (see Eq. 6): 1) the integrated annual activity excreted $A_{t}\left(\mu \mathrm{Bq}\right.$ of $\left.{ }^{239+240} \mathrm{Pu} \mathrm{y}^{-1}\right)$; and 2) the applicable age-specific (50-y) committed effective dose equivalent conversion factor, which is expressed as the $\mathrm{CF}_{\text {CEDE }}\left(\mathrm{Sv}\right.$ or rem) per ${ }^{239+240} \mathrm{Pu}$ activity excretion integrated over the year of measurement ( $\mu \mathrm{Bq} \mathrm{y}^{-1}$; see Table 2$)$.

$$
\mathrm{CEDE}_{\text {age group }}=A_{T}\left(\text { for }{ }^{239+249} \mathrm{Pu}\right) \times \mathrm{CF}_{\mathrm{CEDE}(\text { age group })} \quad \text { Eq. } 6
$$

The data supporting the derivation of the age-specific, whole-body effective dose equivalents per unit of ${ }^{239+240} \mathrm{Pu}$ excreted over the year of measurement $\left(\mu \mathrm{Bq} \mathrm{y}^{-1}\right)$ appearing in Table 2 are determined using data tabulated in Tables A-6 through A-10 of Appendix A. Illustrative examples of the application of these algorithms to hypothetical measurement data are presented in Appendix B.

\section{Procedures for Estimating Age-Dependent, Calendar Year Total Effective Dose Equivalent (TEDE) From Radionuclide-Specific, Age-Dependent, CEDE(s)}

When only ${ }^{137} \mathrm{Cs}$ or only ${ }^{239+240} \mathrm{Pu}$ measurements are reported for an individual of a particular age group in a calendar year, then the total effective dose equivalent (TEDE) assigned due to intakes incurred by an individual during the calendar year corresponds to the CEDE for the measured radionuclide. When both ${ }^{137} \mathrm{Cs}$ whole-body counting and AMS measurement(s) of daily ${ }^{239+240} \mathrm{Pu}$ excretion rate are reported for an individual in a calendar year, then the total effective dose equivalent (TEDE) assigned to the year of measurement that is due to intakes incurred by an individual during the calendar year in which the measurement was made corresponds to the sum of both radionuclide-specific CEDEs as shown in Eq. 7.

$$
\mathrm{TEDE}_{\text {age group }}=\mathrm{CEDE}_{\text {age group }} \text { for }{ }^{137} \mathrm{Cs}+\mathrm{CEDE}_{\text {age group }} \text { for }{ }^{239+240} \mathrm{Pu} \quad \text { Eq. } 7
$$

The TEDE is reported in units of mrem $\mathrm{y}^{-1}$ (and is converted by the following relationships, $1 \mathrm{~Sv}=10^{2} \mathrm{rem}=10^{5} \mathrm{mrem}$ ) for comparison to the $15 \mathrm{mrem} \mathrm{y}^{-1}$ maximum dose limit adopted as a standard for the RMI. 
Table 2. Age dependent Conversion Factors ( $\left.\mathrm{CF}_{\mathrm{CEDE}}\right)$ representing the age-dependent, whole-body, (50-y) committed effective dose equivalent (CEDE) per total amount of ${ }^{239+240} \mathrm{Pu}$ activity excreted during the calendar year $\left(\mu \mathrm{Bq} \mathrm{y}^{-1}\right)^{\mathrm{a}}$

\begin{tabular}{|c|c|c|}
\hline SexlAge & Sv per $\mu \mathrm{Bq} \mathrm{y}^{-1} \mathrm{~b}$ & rem per $\mu B q y^{-1} b$ \\
\hline Adult (> $17 \mathrm{y})$ & $3.3 \times 10^{-7}$ & $3.3 \times 10^{-5}$ \\
\hline Teenager (12 to $17 \mathrm{y})$ & $5.0 \times 10^{-7}$ & $5.0 \times 10^{-5}$ \\
\hline Adolescent (range: 7 to $12 \mathrm{y}$ ) & $8.3 \times 10^{-7}$ & $8.3 \times 10^{-5}$ \\
\hline Child (2 to $7 \mathrm{y}$ ) & $1.3 \times 10^{-6}$ & $1.3 \times 10^{-4}$ \\
\hline
\end{tabular}

a Tables A-6 through A-10 in Appendix A contain the data used to derive the $\mathrm{CF}_{\mathrm{CEDE}}$.

b $1 \mathrm{~Sv}=100 \mathrm{rem}$.

\section{INTERPRETING RESULTS FROM COMPARISON OF CALENDAR YEAR TEDE $_{\text {age group }}$ TO 15-mrem $\mathrm{y}^{-1}$ TEDE ADOPTED BY 1998 NUCLEAR CLAIMS TRIBUNAL DECISION}

The calculations used to derive the total dose from internally deposited ${ }^{137} \mathrm{Cs}$ and ${ }^{239+240} \mathrm{Pu}$ constitute a mathematical approach that distills complicated numerical modeling of intricate biokinetic processes into more easily understood, but representative and analytically executable algorithms. For this reason, these algorithms are designed to incorporate conservative simplifying default assumptions so that results constitute overestimates for the calculated doses for comparison to the 15-mrem y-1 maximum dose limit adopted as a standard for the RMI.

This also means that an excess actual lifetime cancer risk will be lower than that predicted from the overestimate of total dose. Nevertheless, any calendar year dose calculated using the mathematical algorithms and simplifying default assumptions described here that either approaches or is equal to or greater than the 15-mrem $\mathrm{y}^{-1}$ TEDE maximum dose limit, adopted as a standard for the RMI, will receive further and more careful dosimetric re-examination. This reevaluation will either assure that the 15 mrem annual limit is achieved or help explain why it may be exceeded. In fact, any estimate of a TEDE for an individual that is calculated from measurement data to yield a value $\geq 10 \mathrm{mrem} \mathrm{y}^{-1}\left(0.1 \mathrm{mSv}^{-1}\right.$, where $\left.1 \mathrm{mSv}=100 \mathrm{mrem}\right)$ will evoke a more complete and accurate dose evaluation, and/or investigation of intake. For example, these actions will initially involve followup measurements and, depending on the results, a dietary evaluation and/or workplace- and residence-history review. 


\section{ACKNOWLEDGMENT}

This work was performed under the auspices of the U. S. Department of Energy by the University of California, Lawrence Livermore National Laboratory under Contract No. W7405-Eng-48 with funding from the U.S. DOE Office of International Health Studies. We thank Ms. Jennifer Luna and especially Ms. Rayla Buchanan for administrative assistance in helping prepare this document. 


\section{REFERENCES}

ACJ \& Associates, Inc. (2004), IMBA EXPERT TM USDOE-Edition (Phase II), Richland, WA, URL: http://www.imbaexpert.com.

Bell, R.T., D. Hickman, L. Yamaguchi, W. Jackson, and T. Hamilton (2002), A Whole-Body Counting Facility in a Remote Enewetak Island Setting, Radiat. Safety J., 83(Suppl. 1), S22-S26 (also Lawrence Livermore National Laboratory, Livermore CA, UCRL-JC-147325).

Brown, T.A., A.A. Marchetti, R.E. Martinelli, C.C. Cox, J.P. Knezovich, and T.F. Hamilton (2004), Actinide Measurements by Accelerator Mass Spectrometry at Lawrence Livermore National Laboratory, Nucl. Instr. Meth. B223-224, 788-793.

Cristy, M., and K.F. Eckerman (1995), RISC Computer Code Collection: SEECAL 2.0-Program to Calculate Age-Dependent Specific Effective Energies, Radiation Shielding Information Center, Oak Ridge National Laboratory, Oak Ridge, TN, ORNL/TM-12351 (December 1993); Addendum Version 2.0 Information (March 1995); CCC-620 (May 1995).

Hamilton, T.F., T.A. Brown, D.P. Hickman, A.A. Marchetti, R.E. Martinelli, and S.R. Kehl (2004), Low-Level Plutonium Bioassay Measurements at the Lawrence Livermore National Laboratory, Technical Basis Document, Lawrence Livermore National Laboratory, Livermore CA, UCRL-MI-232208.

Hamilton, T.F., S.R. Kehl, D.P. Hickman, T.A. Brown, A.A. Marchetti, R.E. Martinelli, K. Johannes, and D. Henry (2006a), Individual Radiation Protection Monitoring in the Marshall Islands: Enewetak Atoll (2002-2004), Lawrence Livermore National Laboratory, Livermore, CA, UCRL-TR-220591.

Hamilton, T.F., S.R. Kehl, D.P. Hickman, T.A. Brown, A.A. Marchetti, R.E. Martinelli, E. Arelong, and S. Langinbelik (2006b), Individual Radiation Protection Monitoring in the Marshall Islands: Rongelap Atoll (2002-2004), Lawrence Livermore National Laboratory, Livermore, CA, UCRL-TR-220590.

Hamilton, T.F., S.R. Kehl, D.P. Hickman, T.A. Brown, A.A. Marchetti, R.E. Martinelli, S. Tibon, and L. Chee (2006c), Individual Radiation Protection Monitoring in the Marshall Islands: Utrōk Atoll (2003-2004), Lawrence Livermore National Laboratory, Livermore, CA, UCRL-TR-220654.

Hamilton, T.F., T.A. Brown, R.E. Martinelli, K.T. Bogen, S.J. Tumey, S.R. Kehl and R. Langston (2007), Low-Level Detection of Plutonium Isotopes in Bioassay Samples from the Marshall Islands Using Accelerator Mass Spectrometry, Lawrence Livermore National Laboratory, Livermore CA, to be submitted Journal of Health Physics. 
Interagency Steering Committee on Radiation Standards (ISCORS) (2002), Final Report: A Method for Estimating Radiation Risk from Total Effective Dose Equivalent (TEDE), Office of Information Policy and Guidance, United States Department of Energy, Washington, DC, ISCORS Technical Report No. 1, July 2002-02, URL: http://www.iscors.org/library.html ; and http://www.eh.doe.gov/oepa.

International Commission on Radiological Protection (ICRP) (1979), Radiation Protection-ICRP Publication 30: Limits for Intakes of Radionuclides by Workers (Pergamon Press, Elmsford, NY), Annals of the ICRP 2(3/4), 1979 (supersedes ICRP Publication 2).

International Commission on Radiological Protection (ICRP) (1980), Radiation Protection-ICRP Publication 30: Supplement to Part 1: Limits for Intakes of Radionuclides by Workers (Pergamon Press, Elmsford, NY), Annals of the ICRP 3(1-4), 1979 (supersedes ICRP Publication 2); see particularly specific effective energies (SEEs) for ${ }^{239} \mathrm{Pu}$ (p. 413-414) and ${ }^{240} \mathrm{Pu}$ (p. 417-418).

International Commission on Radiological Protection (ICRP) (1990), Radiation Protection-ICRP Publication 56: Age-Dependent Doses to Members of the Public from Intake of Radionuclides: Part 1 (Pergamon Press, Elmsford, NY), Annals of the ICRP 20(2), 1989; see particularly Table 1.-1. Reference Organ masses used for calculating SEE (p. 4) and Table 3.-1 Weighting factors for calculation of the effective dose equivalent (p. 12).

International Commission on Radiological Protection (ICRP) (1991), Radiation Protection-ICRP Publication 60: 1990 Recommendations of the International Commission on Radiological Protection, (Pergamon Press, Elmsford, NY), Annals of the ICRP 21(1-3), 1990; see Table 2. Tissue weighting factors (p. 8).

International Commission on Radiological Protection (ICRP) (1994), Radiation Protection-ICRP Publication 67: Age-Dependent Doses to Members of the Public from Intake of Radionuclides: Part 2; Ingestion Dose Coefficients (Pergamon Press, Elmsford, NY), Annals of the ICRP 20(3/4), 1993.

International Commission on Radiological Protection (ICRP) (1995), Radiation Protection-ICRP Publication 69: Age-Dependent Doses to Members of the Public from Intake of Radionuclides: Part 3; Ingestion Dose Coefficients (Pergamon Press, Elmsford, NY), Annals of the ICRP 25(1), 1995.

International Commission on Radiological Protection (ICRP) (1996a), Radiation Protection-ICRP Publication 71: Age-Dependent Doses to Members of the Public from Intake of Radionuclides: Part 4; Inhalation Dose Coefficients (Pergamon Press, Elsevier Science, Inc., Tarrytown, NY), Annals of the ICRP 25(3/4), 1995. 
International Commission on Radiological Protection (ICRP) (1996b), Radiation Protection-ICRP Publication 72: Age-Dependent Doses to Members of the Public from Intake of Radionuclides: Part 5; Compilation of Ingestion and Inhalation Dose Coefficients (Pergamon Press, Elsevier Science, Inc., Tarrytown, NY), Annals of the ICRP 26(1), 1996.

International Commission on Radiological Protection (ICRP) (1998), Radiation Protection-ICRP Publication 78: Individual Monitoring for Internal Exposure of Workers, Replacement of ICRP Publication 54 (Pergamon Press, Elsevier Science, Inc., Tarrytown, NY), Annals of the ICRP 27(3-4), 1997.

Luftig, S.D., and L. Weinstock (1997), OSWER Directive 9200.4-18 Attachment B: Analysis of What Radiation Dose Limit is Protective of Human Health at CERCLA Sites (Including Review of Dose Limits in NRC Decommissioning Rule) in Memorandum: Establishment of Cleanup Levels for CERCLA Sites with Radioactive Contamination, Office of Solid Waste and Emergency Response (OSWER), United States Environmental Protection Agency, Washington, DC, OSWER No. 9200.4-18 (August 22, 1997), URL: (Superfund: EPA Radiation Guidance for CERCLA: Cleanup Levels and ARARs).

http://www.epa.gov/superfund/resources/radiation/radar ars.htm.

Nuclear Claims Tribunal, Republic of the Marshall Islands (NCT/RMI) (2004), Establishment of a Radiation Protection Standard in Claims [web page last updated March 2004; URL http://www.nuclearclaimstribunal.com/claim.htm\# ftn1], Nuclear Claims Tribunal, Republic of the Marshall Islands, Majuro, MH; URL: http://www.nuclearclaimstribunal.com (contact: nctmaj@ntamar.net).

Robison W.L., K.T. Bogen, and C.L. Conrado (1997). An updated dose assessment for resettlement options at Bikini Atoll-a U.S. nuclear test site, Health Phys., Vol. 73(1), $100-114$.

United States Environmental Protection Agency (USEPA) (1994), Supplementary Calculations-Dose-Based Cleanup Levels, in Radiation Site Cleanup: Technical Support Document for the Development of Radionuclide Cleanup Levels in Soil, Office of Air and Radiation, United States Environmental Protection Agency Washington, DC, EPA-402-R96-011 Review Draft (September 1994), Chapter 5, $\S 5.5$ (p. 5-31); URL: http://www.epa.gov/radiation/docs/cleanup/402-r-96-011a.htm 


\section{Appendix A}

\section{Derivation of Age-Dependent, Whole-Body Effective Dose Equivalent (EDE) Conversion Factors for $137 \mathrm{Cs}$ and 239+240Pu}

The derivation of the effective dose equivalent (EDE) conversion factors for ${ }^{137} \mathrm{Cs}$ and committed effective dose equivalent (CEDE) conversion factors for ${ }^{239+240} \mathrm{Pu}$ are presented in this appendix. Tables A-1 through A-5 show the information used for deriving ${ }^{137} \mathrm{Cs}$ agespecific, whole-body EDE conversion factors. Tables A-6 through A-10 contains information needed for deriving ${ }^{239+240} \mathrm{Pu}$ age-specific, whole-body CEDE conversion factors. Additionally, the contribution to age-specific whole-body CEDE from ${ }^{239+240} \mathrm{Pu}$ deposited in the upper and lower large intestines is described and found to be insignificant (see Table A7 to $A-10)$ 
Table A-1. Derivation of ${ }^{137} \mathrm{Cs}$ whole-body effective dose equivalent (EDE) conversion factors applicable to adult male.

\begin{tabular}{|c|c|c|c|c|}
\hline Target organ & $\begin{array}{c}\text { Tissue } \\
\text { weighting } \\
\text { factor }^{\mathrm{a}}\end{array}$ & $\begin{array}{c}\text { Specific } \\
\text { effective energy } \\
\text { from }{ }^{137} \mathrm{Cs} \\
\left(\mathrm{SEE}=\mathrm{Sv} \mathrm{t}^{-1}\right)^{\mathrm{b}}\end{array}$ & $\begin{array}{c}\text { Specific } \\
\text { effective energy } \\
\text { from }{ }^{137 m_{B a}} \\
\left(S E E=S v t^{-1}\right)^{b}\end{array}$ & $\begin{array}{c}\text { Organ-specific } \\
\text { EDE conversion } \\
\text { factor } \\
\left(\mathrm{Sv} \mathrm{t}^{-1}\right)^{\mathrm{c}}\end{array}$ \\
\hline Gonads & 0.25 & $4.69 \times 10^{-16}$ & $8.01 \times 10^{-16}$ & $3.18 \times 10^{-16}$ \\
\hline Breasts & 0.15 & $4.69 \times 10^{-16}$ & $5.38 \times 10^{-16}$ & $1.51 \times 10^{-16}$ \\
\hline Lung tissue & 0.12 & $4.69 \times 10^{-16}$ & $6.64 \times 10^{-16}$ & $1.36 \times 10^{-16}$ \\
\hline Red bone marrow & 0.12 & $4.69 \times 10^{-16}$ & $6.37 \times 10^{-16}$ & $1.33 \times 10^{-16}$ \\
\hline Stomach wall & 0.06 & $4.69 \times 10^{-16}$ & $7.08 \times 10^{-16}$ & $7.06 \times 10^{-17}$ \\
\hline Adrenals & 0.06 & $4.69 \times 10^{-16}$ & $7.69 \times 10^{-16}$ & $7.43 \times 10^{-17}$ \\
\hline Lower large intestine & 0.06 & $4.69 \times 10^{-16}$ & $7.59 \times 10^{-16}$ & $7.37 \times 10^{-17}$ \\
\hline Upper large intestine & 0.06 & $4.69 \times 10^{-16}$ & $7.33 \times 10^{-16}$ & $7.21 \times 10^{-17}$ \\
\hline Small intestine wall & 0.06 & $4.69 \times 10^{-16}$ & $7.79 \times 10^{-16}$ & $7.49 \times 10^{-17}$ \\
\hline Thyroid & 0.03 & $4.69 \times 10^{-16}$ & $7.00 \times 10^{-16}$ & $3.51 \times 10^{-17}$ \\
\hline Bone surface & 0.03 & $2.35 \times 10^{-16}$ & $6.08 \times 10^{-16}$ & $2.53 \times 10^{-17}$ \\
\hline \multicolumn{4}{|c|}{$\Sigma=$ Whole-body EDE conversion factor $\left(\mathrm{Sv} \mathrm{t}^{-1}\right)$} & $1.16 \times 10^{-15}$ \\
\hline
\end{tabular}

a From ICRP (1990).

b Computed using SEECAL software (Cristy and Eckerman, 1995).

c Derived as product of tissue weighting factor and sum of specific effective energies for beta

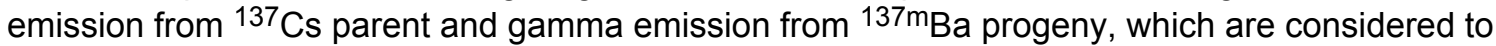
be present in secular equilibrium. 
Table A-2. Derivation of ${ }^{137} \mathrm{Cs}$ whole-body effective dose equivalent (EDE) conversion factors applicable to adult female.

\begin{tabular}{|c|c|c|c|c|}
\hline Target organ & $\begin{array}{l}\text { Tissue } \\
\text { weighting }^{\text {factor }^{\mathrm{a}}}\end{array}$ & $\begin{array}{c}\text { Specific } \\
\text { effective energy } \\
\text { from }{ }^{137} \mathrm{Cs} \\
\left(\mathrm{SEE}=\mathrm{Sv} \mathrm{t} \mathrm{t}^{-1}\right)^{\mathrm{b}}\end{array}$ & $\begin{array}{c}\text { Specific } \\
\text { effective energy } \\
\text { from }{ }^{137 m_{B a}} \\
\left(S E E=S v t^{-1}\right)^{b}\end{array}$ & $\begin{array}{c}\text { Organ-specific } \\
\text { EDE conversion } \\
\text { factor } \\
\left(\mathrm{Sv} \mathrm{t} \mathrm{t}^{-1}\right)^{\mathrm{c}}\end{array}$ \\
\hline Ovaries & 0.25 & $5.64 \times 10^{-16}$ & $9.32 \times 10^{-16}$ & $3.74 \times 10^{-16}$ \\
\hline Breasts & 0.15 & $5.64 \times 10^{-16}$ & $6.42 \times 10^{-16}$ & $1.81 \times 10^{-16}$ \\
\hline Lung tissue & 0.12 & $5.64 \times 10^{-16}$ & $8.04 \times 10^{-16}$ & $1.64 \times 10^{-16}$ \\
\hline Red bone marrow & 0.12 & $5.64 \times 10^{-16}$ & $7.49 \times 10^{-16}$ & $1.58 \times 10^{-16}$ \\
\hline Uterus & 0.06 & $5.64 \times 10^{-16}$ & $9.63 \times 10^{-16}$ & $9.16 \times 10^{-17}$ \\
\hline Adrenals & 0.06 & $5.64 \times 10^{-16}$ & $9.07 \times 10^{-16}$ & $8.82 \times 10^{-17}$ \\
\hline Lower large intestine & 0.06 & $5.64 \times 10^{-16}$ & $8.30 \times 10^{-16}$ & $8.36 \times 10^{-17}$ \\
\hline Upper large intestine & 0.06 & $5.64 \times 10^{-16}$ & $7.82 \times 10^{-16}$ & $8.07 \times 10^{-17}$ \\
\hline Small intestine wall & 0.06 & $5.64 \times 10^{-16}$ & $9.14 \times 10^{-16}$ & $8.87 \times 10^{-17}$ \\
\hline Thyroid & 0.03 & $5.64 \times 10^{-16}$ & $8.43 \times 10^{-16}$ & $4.22 \times 10^{-17}$ \\
\hline Bone surface & 0.03 & $5.64 \times 10^{-16}$ & $7.06 \times 10^{-16}$ & $3.81 \times 10^{-17}$ \\
\hline \multicolumn{4}{|c|}{$\Sigma=$ Whole-body EDE conversion factor $\left(\mathrm{Sv} \mathrm{t}^{-1}\right)$} & $1.39 \times 10^{-15}$ \\
\hline
\end{tabular}

a From ICRP (1990).

b Computed using SEECAL software (Cristy and Eckerman, 1995).

c Derived as product of tissue weighting factor and sum of specific effective energies for beta emission from ${ }^{137} \mathrm{Cs}$ parent and gamma emission from ${ }^{137 \mathrm{~m} B a}$ progeny, which are considered to be present in secular equilibrium. 
Table A-3. Derivation of ${ }^{137} \mathrm{Cs}$ whole-body effective dose equivalent (EDE) conversion factors applicable to $15( \pm 3)$-y old (teenager).

\begin{tabular}{|c|c|c|c|c|}
\hline Target organ & $\begin{array}{c}\text { Tissue } \\
\text { weighting } \\
\text { factor }^{a}\end{array}$ & $\begin{array}{c}\text { Specific } \\
\text { effective energy } \\
\text { from }{ }^{137} \mathrm{Cs} \\
\left(\mathrm{SEE}=\mathrm{Sv} \mathrm{\textrm {t } ^ { - 1 }}\right)^{\mathrm{b}}\end{array}$ & $\begin{array}{c}\text { Specific } \\
\text { effective energy } \\
\text { from }{ }^{137 m_{B a}} \\
\left(S E E=S v t^{-1}\right)^{b}\end{array}$ & $\begin{array}{c}\text { Organ-specific } \\
\text { EDE conversion } \\
\text { factor } \\
\left(\mathrm{Sv} \mathrm{t}^{-1}\right)^{\mathrm{c}}\end{array}$ \\
\hline Gonads & 0.25 & $5.78 \times 10^{-16}$ & $9.38 \times 10^{-16}$ & $3.79 \times 10^{-16}$ \\
\hline Breasts & 0.15 & $5.78 \times 10^{-16}$ & $6.49 \times 10^{-16}$ & $1.84 \times 10^{-16}$ \\
\hline Lung tissue & 0.12 & $5.78 \times 10^{-16}$ & $8.10 \times 10^{-16}$ & $1.67 \times 10^{-16}$ \\
\hline Red bone marrow & 0.12 & $5.78 \times 10^{-16}$ & $7.49 \times 10^{-16}$ & $1.59 \times 10^{-16}$ \\
\hline Uterus & 0.06 & $5.78 \times 10^{-16}$ & $9.71 \times 10^{-16}$ & $9.30 \times 10^{-17}$ \\
\hline Adrenals & 0.06 & $5.78 \times 10^{-16}$ & $9.11 \times 10^{-16}$ & $8.94 \times 10^{-17}$ \\
\hline Stomach wall & 0.06 & $5.78 \times 10^{-16}$ & $8.21 \times 10^{-16}$ & $8.39 \times 10^{-17}$ \\
\hline Upper large intestine & 0.06 & $5.78 \times 10^{-16}$ & $8.37 \times 10^{-16}$ & $8.49 \times 10^{-17}$ \\
\hline Small intestine wall & 0.06 & $5.78 \times 10^{-16}$ & $9.21 \times 10^{-16}$ & $9.00 \times 10^{-17}$ \\
\hline Thyroid & 0.03 & $5.78 \times 10^{-16}$ & $8.50 \times 10^{-16}$ & $4.28 \times 10^{-17}$ \\
\hline Bone surface & 0.03 & $5.78 \times 10^{-16}$ & $7.33 \times 10^{-16}$ & $3.93 \times 10^{-17}$ \\
\hline \multicolumn{4}{|c|}{$\Sigma=$ Whole-body EDE conversion factor $\left(\mathrm{Sv} \mathrm{t}^{-1}\right)$} & $1.41 \times 10^{-15}$ \\
\hline
\end{tabular}

a From ICRP (1990).

b Computed using SEECAL software (Cristy and Eckerman, 1995).

c Derived as product of tissue weighting factor and sum of specific effective energies for beta emission from ${ }^{137} \mathrm{Cs}$ parent and gamma emission from ${ }^{137 \mathrm{~m}} \mathrm{Ba}$ progeny, which are considered to be present in secular equilibrium. 
Table A-4. Derivation of ${ }^{137} \mathrm{Cs}$ whole-body effective dose equivalent (EDE) conversion factors applicable to $10( \pm 3)$-y old (pre-teenager).

\begin{tabular}{|c|c|c|c|c|}
\hline Target organ & $\begin{array}{l}\text { Tissue } \\
\text { weighting } \\
\text { factor }^{\mathrm{a}}\end{array}$ & $\begin{array}{c}\text { Specific } \\
\text { effective energy } \\
\text { from }{ }^{137} \mathrm{Cs} \\
\left(\mathrm{SEE}=\mathrm{Sv} \mathrm{t}^{-1}\right)^{\mathrm{b}}\end{array}$ & $\begin{array}{c}\text { Specific } \\
\text { effective energy } \\
\text { from }{ }^{137 m_{B a}} \\
\left(S E E=S v t^{-1}\right)^{b}\end{array}$ & $\begin{array}{c}\text { Organ-specific } \\
\text { EDE conversion } \\
\text { factor } \\
\left(\mathrm{Sv} \mathrm{t} \mathrm{t}^{-1}\right)^{\mathrm{c}}\end{array}$ \\
\hline Gonads & 0.25 & $9.78 \times 10^{-16}$ & $1.44 \times 10^{-15}$ & $6.05 \times 10^{-16}$ \\
\hline Breasts & 0.15 & $9.78 \times 10^{-16}$ & $9.24 \times 10^{-16}$ & $2.85 \times 10^{-16}$ \\
\hline Lung tissue & 0.12 & $9.78 \times 10^{-16}$ & $1.20 \times 10^{-15}$ & $2.62 \times 10^{-16}$ \\
\hline Red bone marrow & 0.12 & $9.78 \times 10^{-16}$ & $1.15 \times 10^{-15}$ & $2.55 \times 10^{-16}$ \\
\hline Uterus & 0.06 & $9.78 \times 10^{-16}$ & $1.48 \times 10^{-15}$ & $1.48 \times 10^{-16}$ \\
\hline Adrenals & 0.06 & $9.78 \times 10^{-16}$ & $1.39 \times 10^{-15}$ & $1.42 \times 10^{-16}$ \\
\hline Stomach wall & 0.06 & $9.78 \times 10^{-16}$ & $1.23 \times 10^{-15}$ & $1.33 \times 10^{-16}$ \\
\hline Upper large intestine & 0.06 & $9.78 \times 10^{-16}$ & $1.25 \times 10^{-15}$ & $1.34 \times 10^{-16}$ \\
\hline Small intestine wall & 0.06 & $9.78 \times 10^{-16}$ & $1.41 \times 10^{-15}$ & $1.43 \times 10^{-16}$ \\
\hline Thyroid & 0.03 & $9.78 \times 10^{-16}$ & $1.36 \times 10^{-15}$ & $7.01 \times 10^{-17}$ \\
\hline Bone surface & 0.03 & $9.78 \times 10^{-16}$ & $1.12 \times 10^{-15}$ & $6.30 \times 10^{-17}$ \\
\hline \multicolumn{4}{|c|}{$\Sigma=$ Whole-body EDE conversion factor $\left(\mathrm{Sv} \mathrm{t}^{-1}\right)$} & $2.24 \times 10^{-15}$ \\
\hline
\end{tabular}

a From ICRP (1990).

b Computed using SEECAL software (Cristy and Eckerman, 1995).

c Derived as product of tissue weighting factor and sum of specific effective energies for beta emission

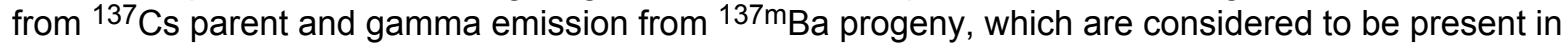
secular equilibrium 
Table A-5. Derivation of ${ }^{137} \mathrm{Cs}$ whole-body effective dose equivalent (EDE) conversion factors applicable to $5( \pm 3)$-y old (child).

\begin{tabular}{|c|c|c|c|c|}
\hline Target organ & $\begin{array}{c}\text { Tissue } \\
\text { weighting }^{\text {factor }}\end{array}$ & $\begin{array}{c}\text { Specific } \\
\text { effective energy } \\
\text { from }{ }^{137} \mathrm{Cs} \\
\left(\mathrm{SEE}=\mathrm{Sv} \mathrm{t}^{-1}\right)^{\mathrm{b}}\end{array}$ & $\begin{array}{c}\text { Specific } \\
\text { effective energy } \\
\text { from }{ }^{137 m_{B a}} \\
\left(S E E=S v t^{-1}\right)^{b}\end{array}$ & $\begin{array}{l}\text { Organ specific } \\
\text { EDE conversion } \\
\text { factor } \\
\left(\mathrm{Sv} \mathrm{t}^{-1}\right)^{\mathrm{c}}\end{array}$ \\
\hline Gonads & 0.25 & $1.63 \times 10^{-15}$ & $2.20 \times 10^{-15}$ & $9.57 \times 10^{-16}$ \\
\hline Breasts & 0.15 & $1.63 \times 10^{-15}$ & $1.45 \times 10^{-15}$ & $4.62 \times 10^{-16}$ \\
\hline Lung tissue & 0.12 & $1.63 \times 10^{-15}$ & $1.86 \times 10^{-15}$ & $4.18 \times 10^{-16}$ \\
\hline Red bone marrow & 0.12 & $1.63 \times 10^{-15}$ & $1.73 \times 10^{-15}$ & $4.03 \times 10^{-16}$ \\
\hline Uterus & 0.06 & $1.63 \times 10^{-15}$ & $2.24 \times 10^{-15}$ & $2.32 \times 10^{-16}$ \\
\hline Adrenals & 0.06 & $1.63 \times 10^{-15}$ & $2.13 \times 10^{-15}$ & $2.26 \times 10^{-16}$ \\
\hline Lower large intestine & 0.06 & $1.63 \times 10^{-15}$ & $1.98 \times 10^{-15}$ & $2.17 \times 10^{-16}$ \\
\hline Upper large intestine & 0.06 & $1.63 \times 10^{-15}$ & $2.00 \times 10^{-15}$ & $2.18 \times 10^{-16}$ \\
\hline Small intestine wall & 0.06 & $1.63 \times 10^{-15}$ & $2.17 \times 10^{-15}$ & $2.28 \times 10^{-16}$ \\
\hline Thyroid & 0.03 & $1.63 \times 10^{-15}$ & $2.17 \times 10^{-15}$ & $1.14 \times 10^{-16}$ \\
\hline Bone surface & 0.03 & $1.63 \times 10^{-15}$ & $1.72 \times 10^{-15}$ & $1.00 \times 10^{-16}$ \\
\hline \multicolumn{4}{|c|}{$\Sigma=$ Whole-body EDE conversion factor $\left(\mathrm{Sv} \mathrm{t}^{-\mathbf{1}}\right)$} & $3.58 \times 10^{-15}$ \\
\hline
\end{tabular}

a From ICRP (1990).

b Computed using SEECAL software (Cristy and Eckerman, 1995).

c Derived as product of tissue weighting factor and sum of specific effective energies for beta

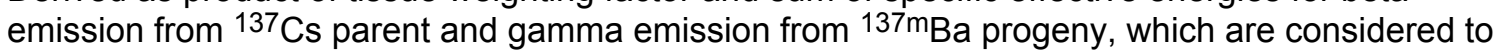
be present in secular equilibrium. 
Table A-6. Age-dependent organ mass $(\mathrm{g})^{\mathrm{a}}$, and ratio of adult to age-group organ masses (dimensionless).

\begin{tabular}{|c|c|c|c|c|c|c|c|c|}
\hline $\begin{array}{l}\text { Target } \\
\text { Organ }\end{array}$ & $\begin{array}{l}\text { Organ } \\
\text { Mass } \\
(g)\end{array}$ & $\begin{array}{l}\text { Ratio: } \\
\text { adult to } \\
\text { adult }\end{array}$ & $\begin{array}{c}15 \text { y (teen) } \\
\text { organ } \\
\text { mass } \\
(g)\end{array}$ & $\begin{array}{l}\text { Ratio: } \\
\text { adult to } \\
\text { teen }\end{array}$ & $\begin{array}{c}10 y \\
\text { (pre-teen) } \\
\text { organ } \\
\text { mass } \\
(g)\end{array}$ & $\begin{array}{l}\text { Ratio: } \\
\text { adult to } \\
\text { pre-teen }\end{array}$ & $\begin{array}{c}5 \text { y (child) } \\
\text { organ mass } \\
\text { (g) }\end{array}$ & $\begin{array}{l}\text { Ratio: } \\
\text { adult to } \\
\text { child }\end{array}$ \\
\hline Lungs & 1000 & 1.00 & 651 & 1.54 & 453 & 2.21 & 290 & 3.45 \\
\hline Liver & 1800 & 1.00 & 1400 & 1.29 & 887 & 2.03 & 584 & 3.08 \\
\hline Cort. BS ${ }^{b}$ & 120 & 1.00 & 120 & 1.00 & 68 & 1.76 & 37 & 3.24 \\
\hline Trab. BS ${ }^{b}$ & 120 & 1.00 & 120 & 1.00 & 68 & 1.76 & 37 & 3.24 \\
\hline Gonads $^{c}$ & 35 & 1.00 & 15.5 & 2.26 & 1.89 & 18.52 & 1.63 & 21.47 \\
\hline ULI Id Wall & 210 & 1.00 & 168 & 1.25 & 93 & 2.26 & 55.2 & 3.80 \\
\hline LLIe Wall & 160 & 1.00 & 127 & 1.26 & 70 & 2.29 & 41.4 & 3.89 \\
\hline
\end{tabular}

a From ICRP (1996a) and used for determining specific effective energy (SEE) for non-adult age groups.

${ }^{b}$ Mass of endostial tissue weight is used to establish ratios for cortical bone surface (Cort. BS) and trabecular bone surface (Trab. BS).

c Testes serve as conservative approximation for mass of gonads, regardless of gender.

${ }^{\mathrm{d}} \mathrm{ULI}=$ upper large intestine wall.

${ }^{\text {e } ~ L L I ~=~ l o w e r ~ l a r g e ~ i n t e s t i n e ~ w a l l . ~}$ 
Table A-7. Derivation of ${ }^{239+240} \mathrm{Pu}$ whole-body committed effective dose equivalent conversion factor (CF $\left.\mathrm{CEDE}\right)$ applicable to adult $(>17 \mathrm{y})$.

\begin{tabular}{|c|c|c|c|c|c|c|c|c|c|}
\hline Lungs & $3.3 \times 10^{-2}$ & $9.1 \times 10^{-5}$ & 0.1 & 0.12 & $1.43 \times 10^{+05}$ & $1.60 \times 10^{-10}$ & 1 & $2.7 \times 10^{-7}$ & \\
\hline Liver & $1.3 \times 10^{-2}$ & $3.7 \times 10^{-5}$ & 0.058 & 0.05 & $5.79 \times 10^{+04}$ & $1.60 \times 10^{-10}$ & 1 & $2.7 \times 10^{-8}$ & \\
\hline Trab.BS & $4.3 \times 10^{-3}$ & $1.2 \times 10^{-5}$ & 0.21 & 0.01 & $1.85 \times 10^{+04}$ & $1.60 \times 10^{-10}$ & 1 & $6.2 \times 10^{-9}$ & \\
\hline Gonadsi & $1.7 \times 10^{-5}$ & $4.5 \times 10^{-8}$ & 3 & 0.2 & $7.16 \times 10^{+01}$ & $1.60 \times 10^{-10}$ & 1 & $6.9 \times 10^{-9}$ & \\
\hline ULI & $2.5 \times 10^{-7}$ & $6.8 \times 10^{-10}$ & 0.0023 & 0.05 & $1.08 \times 10^{+00}$ & $1.60 \times 10^{-10}$ & 1 & $2.0 \times 10^{-14}$ & \\
\hline LLI & $4.5 \times 10^{-7}$ & $1.2 \times 10^{-9}$ & 0.0038 & 0.05 & $1.93 \times 10^{+00}$ & $1.60 \times 10^{-10}$ & 1 & $5.9 \times 10^{-14}$ & \\
\hline
\end{tabular}

a $1 \mathrm{~Bq}=1$ transformation per second $\left(\mathrm{t} \mathrm{s}^{-1}\right)$, therefore units for equilibrium organ content can also be expressed as $\mathrm{s} \mathrm{s}^{-1}$ per $\mu \mathrm{Bq} \mathrm{d}^{-1}$ excreted.

${ }^{b}$ Values in units of Bq per $\mu \mathrm{Bq} \mathrm{d}{ }^{-1}$ excreted are converted to Bq per $\mu \mathrm{Bq} \mathrm{y}^{-1}$ excreted by dividing the value in the first column by $365 \mathrm{~d} \mathrm{y}^{-1}$.

c Specific effective energy (SEE) is the energy (MeV) absorbed per unit mass ( $g$ ) of organ tissue per transformation ( $\mathrm{t}$ ).

${ }^{d}$ Tissue weighting factors are from ICRP Publication 60 (ICRP, 1991) and represent the fraction of the overall health risk for developing cancer from uniform, whole-body irradiation, attributed to each specific organ.

${ }^{\mathrm{e}}$ Equates to product of $\mathrm{t} / \mathrm{s}$ per $\mu \mathrm{Bq} \mathrm{d}^{-1}$ excreted; $8.64 \times 10^{4} \mathrm{~s} \mathrm{~d}^{-1}$; and 50-y period of commitment ( $\mu \mathrm{Bq}^{-1}$ over $\left.50 \mathrm{y}\right)$.

f Equates to product $1.6 \times 10^{-13} \mathrm{~J} \mathrm{Mev}^{-1} ; 1.0 \times 10^{3} \mathrm{~g} \mathrm{~kg}^{-1}$; and $1 \mathrm{~Sv} /\left(\mathrm{J} \mathrm{kg}^{-1}\right)$.

g See Table A-6 for values.

${ }^{\mathrm{h}}$ Equates to the product of $\mathrm{t} \mathrm{s}^{-1}$ per $\mu \mathrm{Bq} \mathrm{y} \mathrm{y}^{-1}$ excreted; $365 \mathrm{~d} \mathrm{y}^{-1} ; 8.64 \times 10^{4} \mathrm{~s} \mathrm{~d}^{-1} ; 50 \mathrm{y}$; SEE [MeV/(g t)]; and units conversion factor [(Sv g)/MeV].

i Testes serve as an approximation for mass of gonads, regardless of gender.

Note: Cort.BS = Cortical bone surface; Trab.BS = Trabecular bone surface; ULI = upper large intestine; and LLI = lower large intestine. 
Table A-8. Derivation of ${ }^{239+240 P u}$ whole-body committed effective dose equivalent conversion factor (CFCEDE) applicable to teenager (12 to $17 \mathrm{y}$ ).

\begin{tabular}{|c|c|c|c|c|c|c|c|c|c|}
\hline Organ & $\begin{array}{l}\text { Equilibrium } \\
\text { organ content } \\
\text { (Bq per } \mu \mathrm{Bq} \\
\mathrm{d}^{-1} \text { excreted) }\end{array}$ & $\begin{array}{l}\text { Equilibrium } \\
\text { organ content } \\
\text { (Bq per } \mu \mathrm{Bq} \\
\text { excreted } \\
\text { in } 1 \mathrm{yr})^{\mathbf{b}}\end{array}$ & $\underset{[\mathrm{MeV} /(\mathrm{g} \mathrm{t})]^{\mathrm{c}}}{\mathrm{SEE}}$ & $\begin{array}{c}\text { Tissue } \\
\text { weighting } \\
\text { factor }^{d}\end{array}$ & $\begin{array}{c}\text { Transformatio } \\
\text { in organ ove } \\
50 \text { years }^{\text {e }}\end{array}$ & $\begin{array}{cc} & \text { Units } \\
\text { ons } & \text { conversion } \\
\text { er } & \text { factor } \\
& (\text { Sv g/Mev })^{f}\end{array}$ & $\begin{array}{l}\text { Organ mass } \\
\text { ratio (relative } \\
\text { to adult } \\
\text { organ) }^{g}\end{array}$ & $\begin{array}{l}\text { CFCEDE }^{\mathrm{h}} \\
\text { (Sv per } \mu \mathrm{Bq} \\
\text { excreted } \\
\text { in } 1 \mathrm{y})\end{array}$ & $\begin{array}{c}\text { CFCEDE }^{\mathrm{h}} \\
\text { (mrem per } \\
\mu \text { Bq excreted } \\
\text { in } 1 \mathrm{y} \text { ) }\end{array}$ \\
\hline Lungs & $3.3 \times 10^{-2}$ & $9.1 \times 10^{-5}$ & 0.1 & 0.12 & $1.43 \times 10^{5}$ & $1.60 \times 10^{-10}$ & 1.54 & $4.2 \times 10^{-7}$ & \\
\hline Liver & $1.3 \times 10^{-2}$ & $3.7 \times 10^{-5}$ & 0.058 & 0.05 & $5.79 \times 10^{4}$ & $1.60 \times 10^{-10}$ & 1.29 & $3.5 \times 10^{-8}$ & \\
\hline Cort.BS & $1.3 \times 10^{-2}$ & $3.4 \times 10^{-5}$ & 0.21 & 0.01 & $5.40 \times 10^{4}$ & $1.60 \times 10^{-10}$ & 1 & $1.8 \times 10^{-8}$ & \\
\hline Trab.BS & $4.3 \times 10^{-3}$ & $1.2 \times 10^{-5}$ & 0.21 & 0.01 & $1.85 \times 10^{4}$ & $1.60 \times 10^{-10}$ & 1 & $6.2 \times 10^{-9}$ & \\
\hline Gonads $^{i}$ & $1.7 \times 10^{-5}$ & $4.5 \times 10^{-8}$ & 3 & 0.2 & $7.16 \times 10^{1}$ & $1.60 \times 10^{-10}$ & 2.26 & $1.6 \times 10^{-8}$ & \\
\hline ULI & $2.5 \times 10^{-7}$ & $6.8 \times 10^{-10}$ & 0.0023 & 0.05 & $1.08 \times 10^{0}$ & $1.60 \times 10^{-10}$ & 1.25 & $2.5 \times 10^{-14}$ & \\
\hline \multirow[t]{2}{*}{ LLI } & $4.5 \times 10^{-7}$ & $1.2 \times 10^{-9}$ & 0.0038 & 0.05 & $1.93 \times 10^{0}$ & $1.60 \times 10^{-10}$ & 1.26 & $7.4 \times 10^{-14}$ & \\
\hline & & & & & & & $\Sigma=$ & $5.0 \times 10^{-7}$ & $5.0 \times 10^{-2}$ \\
\hline
\end{tabular}

a $1 \mathrm{~Bq}=1$ transformation per second $\left(\mathrm{t} \mathrm{s}^{-1}\right)$, therefore units for equilibrium organ content can also be expressed as $\mathrm{t} \mathrm{s}{ }^{-1}$ per $\mu \mathrm{Bq} \mathrm{d}^{-1}$ excreted.

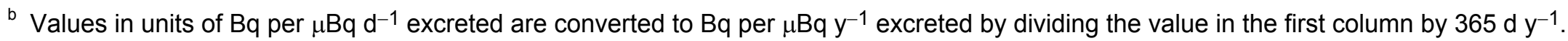

c Specific effective energy (SEE) is the energy (MeV) absorbed per unit mass ( $\mathrm{g}$ ) of organ tissue per transformation ( $\mathrm{t}$ ).

$\mathrm{d}$ Tissue weighting factors are from ICRP Publication 60 (ICRP, 1991) and represent the fraction of the overall health risk for developing cancer from uniform, whole-body irradiation, attributed to each specific organ.

e Equates to product of $\mathrm{t} \mathrm{s}^{-1}$ per $\mu \mathrm{Bq} \mathrm{d}^{-1}$ excreted; $8.64 \times 10^{4} \mathrm{~s} \mathrm{~d}^{-1}$; and 50 -y period of commitment ( $\left.\mu \mathrm{BBq}^{-1} \mathrm{over}^{50} \mathrm{y}\right)$.

f Equates to product $1.6 \times 10^{-13} \mathrm{~J} \mathrm{Mev}^{-1} ; 1.0 \times 10^{3} \mathrm{~g} \mathrm{~kg}^{-1}$; and $1 \mathrm{~Sv} /\left(\mathrm{J} \mathrm{kg}^{-1}\right)$.

S See Table A-6 for values.

h Equates to the product of t/s per $\mu \mathrm{Bq} \mathrm{y}^{-1}$ excreted; $365 \mathrm{~d} \mathrm{y}^{-1} ; 8.64 \times 10^{4} \mathrm{~s} \mathrm{~d}^{-1} ; 50 \mathrm{y} ; \mathrm{SEE}$ [MeV/(g t)]; and units conversion factor [(Sv g)/MeV].

i Testes serve as an approximation for mass of gonads, regardless of gender.

Note: Cort.BS = Cortical bone surface; Trab.BS = Trabecular bone surface; ULI = upper large intestine; and LLI = lower large intestine. 
Table A-9. Derivation of $239+240 \mathrm{Pu}$ whole-body committed effective dose equivalent conversion factor (CF CEDE) applicable pre-teenager (7 to $12 \mathrm{y})$.

\begin{tabular}{|c|c|c|c|c|c|c|c|c|c|}
\hline Organ & $\begin{array}{l}\text { Equilibrium } \\
\text { organ content } \\
\text { (Bq per } \mu \mathrm{Bq} \\
\mathrm{d}^{-1} \text { excreted) }\end{array}$ & $\begin{array}{l}\text { Equilibrium } \\
\text { organ content } \\
\text { (Bq per } \mu \mathrm{Bq} \\
\text { excreted } \\
\text { in } 1 \mathrm{yr})^{\mathbf{b}}\end{array}$ & $\underset{[\operatorname{MeV} /(g \mathrm{t})]^{\mathrm{c}}}{\mathrm{SEE}}$ & $\begin{array}{c}\text { Tissue } \\
\text { weighting } \\
\text { factor }^{d}\end{array}$ & $\begin{array}{c}\text { Transformation } \\
s \text { in organ over } \\
50 \text { years }^{\mathrm{e}}\end{array}$ & $\begin{array}{c}\text { Units } \\
\text { conversion } \\
\text { factor } \\
(\text { Sv g/Mev) }\end{array}$ & $\begin{array}{l}\text { Organ mass } \\
\text { ratio (relative } \\
\text { to adult } \\
\text { organ) }^{g}\end{array}$ & $\begin{array}{l}\text { CFCEDE }^{\mathrm{h}} \\
\text { (Sv per } \mu \mathrm{Bq} \\
\text { excreted } \\
\text { in } 1 \mathrm{y})\end{array}$ & $\begin{array}{c}\text { CFCEDE }^{\mathrm{h}} \\
\text { (mrem per } \\
\mu B q \text { excreted } \\
\text { in } 1 \mathrm{y})\end{array}$ \\
\hline Lungs & $3.3 \times 10^{-2}$ & $9.1 \times 10^{-5}$ & 0.1 & 0.12 & $1.43 \times 10^{5}$ & $1.60 \times 10^{-10}$ & 2.21 & $6.1 \times 10^{-7}$ & \\
\hline Liver & $1.3 \times 10^{-2}$ & $3.7 \times 10^{-5}$ & 0.058 & 0.05 & $5.79 \times 10^{4}$ & $1.60 \times 10^{-10}$ & 2.03 & $5.5 \times 10^{-8}$ & \\
\hline Cort. BS & $1.3 \times 10^{-2}$ & $3.4 \times 10^{-5}$ & 0.21 & 0.01 & $5.40 \times 10^{4}$ & $1.60 \times 10^{-10}$ & 1.76 & $3.2 \times 10^{-8}$ & \\
\hline Trab. BS & $4.3 \times 10^{-3}$ & $1.2 \times 10^{-5}$ & 0.21 & 0.01 & $1.85 \times 10^{4}$ & $1.60 \times 10^{-10}$ & 1.76 & $1.1 \times 10^{-8}$ & \\
\hline Gonads ${ }^{i}$ & $1.7 \times 10^{-5}$ & $4.5 \times 10^{-8}$ & 3 & 0.2 & $7.16 \times 10^{1}$ & $1.60 \times 10^{-10}$ & 18.52 & $1.3 \times 10^{-7}$ & \\
\hline ULI & $2.5 \times 10^{-7}$ & $6.8 \times 10^{-10}$ & 0.0023 & 0.05 & $1.08 \times 10^{0}$ & $1.60 \times 10^{-10}$ & 2.26 & $4.5 \times 10^{-14}$ & \\
\hline \multirow[t]{2}{*}{ LLI } & $4.5 \times 10^{-7}$ & $1.2 \times 10^{-9}$ & 0.0038 & 0.05 & $1.93 \times 10^{0}$ & $1.60 \times 10^{-10}$ & 2.29 & $1.3 \times 10^{-13}$ & \\
\hline & & & & & & & $\Sigma=$ & $8.3 \times 10^{-7}$ & $8.3 \times 10^{-2}$ \\
\hline
\end{tabular}

a $1 \mathrm{~Bq}=1$ transformation per second $\left(\mathrm{t} \mathrm{s}^{-1}\right)$, therefore units for equilibrium organ content can also be expressed as $\mathrm{t} \mathrm{s} \mathrm{s}^{-1}$ per $\mu \mathrm{Bq} \mathrm{d}^{-1}$ excreted.

${ }^{b}$ Values in units of Bq per $\mu \mathrm{Bq} \mathrm{d}{ }^{-1}$ excreted are converted to Bq per $\mu \mathrm{Bq}^{-1}$ excreted by dividing the value in the first column by $365 \mathrm{~d} \mathrm{y}^{-1}$.

${ }^{c}$ Specific effective energy (SEE) is the energy (MeV) absorbed per unit mass $(\mathrm{g})$ of organ tissue per transformation ( $\mathrm{t}$ ).

d Tissue weighting factors are from ICRP Publication 60 (ICRP, 1991) and represent the fraction of the overall health risk for developing cancer from uniform, whole-body irradiation, attributed to each specific organ.

${ }^{\mathrm{e}}$ Equates to product of $\mathrm{t} / \mathrm{s}$ per $\mu \mathrm{Bq} \mathrm{d} \mathrm{d}^{-1}$ excreted; $8.64 \times 10^{4} \mathrm{~s} \mathrm{~d}^{-1}$; and 50 -y period of commitment $\left(\mathrm{t} \mu \mathrm{Bq}^{-1}\right.$ over $\left.50 \mathrm{y}\right)$.

f Equates to product $1.6 \times 10^{-13} \mathrm{~J} \mathrm{Mev}^{-1} ; 1.0 \times 10^{3} \mathrm{~g} \mathrm{~kg}^{-1}$; and $1 \mathrm{~Sv} /\left(\mathrm{J} \mathrm{kg}^{-1}\right)$.

${ }^{g}$ See Table A-6 for values.

h Equates to the product of $\mathrm{t} \mathrm{s}^{-1}$ per $\mu \mathrm{Bq} \mathrm{y} \mathrm{y}^{-1}$ excreted; $365 \mathrm{~d} \mathrm{y}^{-1} ; 8.64 \times 10^{4} \mathrm{~s} \mathrm{~d}^{-1} ; 50 \mathrm{y}$; SEE [MeV/(g t)]; and units conversion factor [(Sv $\mathrm{g} / \mathrm{MeV}]$.

i Testes serve as an approximation for mass of gonads, regardless of gender.

Note: Cort.BS = Cortical bone surface; Trab.BS = Trabecular bone surface; ULI = upper large intestine; and LLI = lower large intestine. 
Table A-10. Derivation of ${ }^{239+240 P u}$ whole-body committed effective dose equivalent conversion factor (CF CEDE) applicable to child (2 to $7 \mathrm{y}$ ).

\begin{tabular}{|c|c|c|c|c|c|c|c|c|c|}
\hline Organ & $\begin{array}{l}\text { Equilibrium } \\
\text { organ content } \\
\text { (Bq per } \mu \mathrm{Bq} \\
\mathrm{d}^{-1} \text { excreted) }\end{array}$ & $\begin{array}{l}\text { Equilibrium } \\
\text { organ content } \\
\text { (Bq per } \mu \mathrm{Bq} \\
\text { excreted } \\
\text { in } 1 \mathrm{yr})^{\mathrm{b}}\end{array}$ & $\begin{array}{c}\text { SEE } \\
{[\mathrm{MeV} /(g \mathrm{t})]^{\mathrm{c}}}\end{array}$ & $\begin{array}{c}\text { Tissue } \\
\text { weighting } \\
\text { factor }^{d}\end{array}$ & $\begin{array}{c}\text { Transformations } \\
\text { in organ over } \\
50 \text { years }^{\mathrm{e}}\end{array}$ & $\begin{array}{c}\text { Units } \\
\text { conversion } \\
\text { factor } \\
(\mathrm{Sv} \text { g/Mev) }\end{array}$ & $\begin{array}{l}\text { Organ mass } \\
\text { ratio (relative } \\
\text { to adult } \\
\text { organ) }^{\mathrm{g}}\end{array}$ & $\begin{array}{c}\mathrm{CF}_{\mathrm{CEDE}}{ }^{\mathrm{h}} \\
\text { e (Sv per } \mu \mathrm{Bq} \\
\text { excreted } \\
\text { in } 1 \mathrm{y})\end{array}$ & $\begin{array}{c}\text { CF }_{\text {CEDE }}{ }^{\mathrm{h}} \\
\text { (mrem per } \\
\mu \mathrm{Bq} \text { excreted } \\
\text { in } 1 \mathrm{y})\end{array}$ \\
\hline Lungs & $3.3 \times 10^{-2}$ & $9.1 \times 10^{-5}$ & 0.1 & 0.12 & $1.43 \times 10^{5}$ & $1.60 \times 10^{-10}$ & 3.45 & $9.5 \times 10^{-7}$ & \\
\hline Liver & $1.3 \times 10^{-2}$ & $3.7 \times 10^{-5}$ & 0.058 & 0.05 & $5.79 \times 10^{4}$ & $1.60 \times 10^{-10}$ & 3.08 & $8.3 \times 10^{-8}$ & \\
\hline Cort. BS & $1.3 \times 10^{-2}$ & $3.4 \times 10^{-5}$ & 0.21 & 0.01 & $5.40 \times 10^{4}$ & $1.60 \times 10^{-10}$ & 3.24 & $5.9 \times 10^{-8}$ & \\
\hline Gonads $^{i}$ & $1.7 \times 10^{-5}$ & $4.5 \times 10^{-8}$ & 3 & 0.2 & $7.16 \times 10^{1}$ & $1.60 \times 10^{-10}$ & 21.47 & $1.5 \times 10^{-7}$ & \\
\hline ULI & $2.5 \times 10^{-7}$ & $6.8 \times 10^{-10}$ & 0.0023 & 0.05 & $1.08 \times 10^{0}$ & $1.60 \times 10^{-10}$ & 3.8 & $7.6 \times 10^{-14}$ & \\
\hline \multirow[t]{2}{*}{ LLI } & $4.5 \times 10^{-7}$ & $1.2 \times 10^{-9}$ & 0.0038 & 0.05 & $1.93 \times 10^{0}$ & $1.60 \times 10^{-10}$ & 3.89 & $2.3 \times 10^{-13}$ & \\
\hline & & & & & & & $\Sigma=$ & $1.3 \times 10^{-6}$ & $1.3 \times 10^{-1}$ \\
\hline
\end{tabular}

a $1 \mathrm{~Bq}=1$ transformation per second $\left(\mathrm{t} \mathrm{s}^{-1}\right)$, therefore units for equilibrium organ content can also be expressed as $\mathrm{t} \mathrm{s}^{-1}$ per $\mu \mathrm{Bq} \mathrm{d}^{-1}$ excreted.

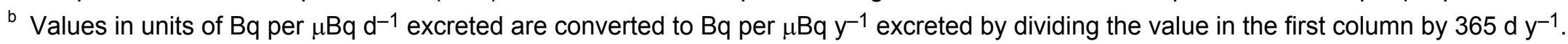

${ }^{c}$ Specific effective energy (SEE) is the energy (MeV) absorbed per unit mass $(\mathrm{g})$ of organ tissue per transformation ( $\mathrm{t}$ ).

${ }^{d}$ Tissue weighting factors are from ICRP Publication 60 (ICRP, 1991) and represent the fraction of the overall health risk for developing cancer from uniform, whole-body irradiation, attributed to each specific organ.

${ }^{\mathrm{e}}$ Equates to product of $\mathrm{t} \mathrm{s}^{-1}$ per $\mu \mathrm{Bq} \mathrm{d} \mathrm{d}^{-1}$ excreted; $8.64 \times 10^{4} \mathrm{~s} \mathrm{~d}^{-1}$; and 50 -y period of commitment ( $\mathrm{t} / \mu \mathrm{Bq}$ over $\left.50 \mathrm{y}\right)$.

f Equates to product $1.6 \times 10^{-13} \mathrm{~J} \mathrm{Mev}^{-1} ; 1.0 \times 10^{3} \mathrm{~g} \mathrm{~kg}^{-1}$; and $1 \mathrm{~Sv} /\left(\mathrm{J} \mathrm{kg}^{-1}\right)$.

g See Table A-6 for values.

h Equates to the product of $\mathrm{s} \mathrm{s}^{-1}$ per $\mu \mathrm{Bq} \mathrm{y} \mathrm{y}^{-1}$ excreted; $365 \mathrm{~d} \mathrm{y}^{-1} ; 8.64 \times 10^{4} \mathrm{~s} \mathrm{~d}^{-1} ; 50 \mathrm{y}$; SEE [MeV/(g t)]; and units conversion factor [(Sv g)/MeV].

i Testes serve as an approximation for mass of gonads, regardless of gender.

Note: Cort.BS = Cortical bone surface; Trab.BS = Trabecular bone surface; ULI = upper large intestine; and LLI = lower large intestine. 


\section{Appendix B}

\section{Illustrative Sample Calculations for Hypothetical Measurements}


The dosimetric calculations for determining the age-specific, annual TEDE $E_{\text {age group }}$

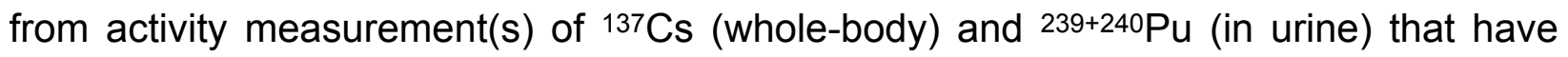
been applied since 2005 for the Marshall Islands radiological surveillance monitoring program involve application of Equations 1, and 3 through 7 in the text. The dosimetric calculations for determining an age-dependent, annual $\mathrm{CEDE}_{\text {age group }}$ for ${ }^{137} \mathrm{Cs}$ remain the same as that performed prior to 2005. However, the dosimetric calculation performed beginning in 2005 for determining an age-dependent, annual CEDE $E_{\text {age group }}$

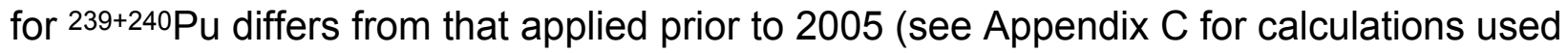
from 1998 to 2004 to obtain an age-dependent, annual CEDE age group for ${ }^{239+240} \mathrm{Pu}$ ). The calculation for the age-dependent, annual CEDE for ${ }^{239+240} \mathrm{Pu}$ was changed beginning in 2005 because it is more in agreement with currently accepted dosimetry and biokinetic modeling practice used by the U.S. Department of Energy (ACJ \& Associates, Inc., 2004). As indicated in Eq. 7 in the text, the age-specific, annual TEDE $E_{\text {age group }}$ for an individual during a calendar year is the sum of age-specific, annual CEDE age group for both ${ }^{137} \mathrm{Cs}$ (from whole-body counting) and ${ }^{239+240} \mathrm{Pu}$ (excreted in urine), if the activities of both are measured; or, can be the age-specific, annual $C E_{\text {age group }}$ for either one, if the activity of only one is measured.

Six examples (I-VI) of calculations are presented to illustrate the computation of an annual age-specific $C E D E_{\text {age group }}$ for a hypothetical volunteer. The first three

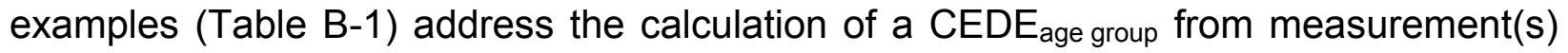
of ${ }^{137} \mathrm{Cs}$ activity by whole-body counting. The next three examples (Table B-2) show the

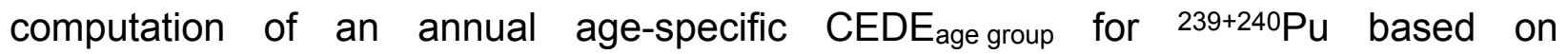
measurement(s) of ${ }^{239+240} \mathrm{Pu}$ activity excreted in urine. The purpose of these six example calculations is to make transparent the method described in the text. It is important to note that these calculations are all examples for hypothetical human volunteers and so the results from the examples demonstrate methodology and do not apply to any specific individual currently involved in the Marshall Islands individual radiological surveillance monitoring program. Additionally, it is important to restate here the process yields conservative estimates of dose and a result $\geq 10$ mrem-y will normally evoke a more accurate and complete dose calculation and/or investigation of intake.

\section{Example Calculations for Deriving CEDEage group from Measurement(s) of ${ }^{137} \mathrm{Cs}$ Activity by Whole-Body Counting}

The first step in the process of determining a CEDE age group for ${ }^{137} \mathrm{Cs}$ that is applicable to the hypothetical human volunteer is to apply Eq. B-1 (which is Eq. 1 in the text) with the appropriate information from Table B-1. The result of this calculation is the number of transformations per year $\left(\mathrm{t}^{-1}\right)$ occurring in the body of a hypothetical human volunteer during the year of measurement.

$$
A_{t}=\left[m_{i} t_{i}+m_{N}\left(365-t_{N}\right)+\sum_{i=1}^{N-1} \frac{\left(m_{i}+m_{i+1}\right)}{2}\left(t_{i+1}-t_{i}\right)\right] \times u_{c f}, \text { where } \quad \text { Eq. B-1 }
$$


Table B-1. Data for computing the CEDE age group for ${ }^{137} \mathrm{Cs}$ applicable to a hypothetical volunteer based on measurement(s) of ${ }^{137}$ Cs activity by whole-body counting.

\begin{tabular}{|c|c|c|c|c|c|c|c|}
\hline $\begin{array}{c}\text { Example } \\
\text { no. }\end{array}$ & $\begin{array}{c}\text { Characteristics } \\
\text { of hypothetical } \\
\text { human } \\
\text { volunteer }\end{array}$ & $\begin{array}{l}\text { Total number } \\
\text { of } \\
\text { measurements } \\
\text { performed }(\mathrm{N})\end{array}$ & $\begin{array}{l}\text { Measurement } \\
\text { number (i) }\end{array}$ & $\begin{array}{l}\text { Calendar date for } \\
\text { measurement (i) } \\
\text { during } 365-d \text { year }\end{array}$ & $\begin{array}{l}\text { Numerical } \\
\text { calendar day } \\
\text { representing } \\
\text { time (t) of } \\
\text { measurement } \\
\text { (i) }\end{array}$ & $\begin{array}{l}\text { Recorded } \\
\text { activity (kBq) for } \\
\text { measurement (i) }\end{array}$ & $\begin{array}{l}\text { Applicable dose } \\
\text { conversion factor } \\
\text { [DCF; Sv per } \\
\text { transformation] (see } \\
\text { Table } 1 \text { in text and } \\
\text { also App. A.) }\end{array}$ \\
\hline $\mathbf{I}$ & Adult male & 1 & 1 & October 1 & 274 & 0.19 & $1.16 \times 10^{-15}$ \\
\hline \multirow[t]{2}{*}{ II } & \multirow[t]{2}{*}{ Adult female } & \multirow[t]{2}{*}{2} & 1 & November 1 & 304 & 0.07 & \multirow{2}{*}{$1.39 \times 10^{-15}$} \\
\hline & & & 2 & December 15 & 348 & 0.03 & \\
\hline \multirow[t]{6}{*}{ III } & Teenager & 6 & 1 & June 1 & 152 & 0.700 & \multirow{6}{*}{$1.41 \times 10^{-15}$} \\
\hline & & & 2 & August 2 & 214 & 0.781 & \\
\hline & & & 3 & September 3 & 246 & 0.756 & \\
\hline & & & 4 & October 4 & 277 & 0.742 & \\
\hline & & & 5 & November 5 & 309 & 0.603 & \\
\hline & & & 6 & December 6 & 340 & 0.523 & \\
\hline
\end{tabular}




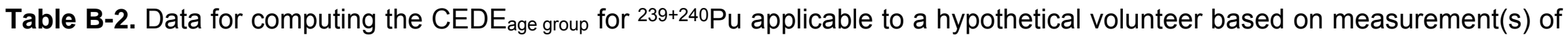
$239+240 \mathrm{Pu}$ activity excreted in a 24 -h urine void.

\begin{tabular}{|c|c|c|c|c|c|c|c|}
\hline $\begin{array}{c}\text { Example } \\
\text { no. }\end{array}$ & $\begin{array}{c}\text { Characteristics } \\
\text { of hypothetical } \\
\text { human } \\
\text { volunteer }\end{array}$ & $\begin{array}{l}\text { Total number of } \\
\text { measurements } \\
\text { performed }(\mathrm{N})\end{array}$ & $\begin{array}{c}\text { Measurement } \\
\text { number (i) }\end{array}$ & $\begin{array}{l}\text { Calendar date for } \\
\text { measurement (i) } \\
\text { during } 365-d \text { year }\end{array}$ & $\begin{array}{l}\text { Numerical } \\
\text { calendar day } \\
\text { representing } \\
\text { time (t) of } \\
\text { measurement }(i)\end{array}$ & $\begin{array}{c}\text { Recorded } \\
\text { activity ( } \mu \mathrm{Bq}) \\
\text { for a } 24-\mathrm{h} \\
\text { urine void (i) }\end{array}$ & $\begin{array}{l}\text { Applicable CF CEDE for } \\
50 \text { y commitment [Sv } \\
\text { per } \mu \mathrm{Bq} / \mathrm{y} \text {; } \text { (see } \\
\text { Table } 2 \text { in text and } \\
\text { also Appendix A) }\end{array}$ \\
\hline IV & Adult & 1 & 1 & July 29 & 210 & 1.0 & $3.3 \times 10^{-7}$ \\
\hline \multirow[t]{2}{*}{$\mathbf{V}$} & \multirow[t]{2}{*}{ Teenager } & \multirow[t]{2}{*}{2} & 1 & April 4 & 94 & 2.0 & \multirow{2}{*}{$5.0 \times 10^{-7}$} \\
\hline & & & 2 & October 29 & 302 & 3.1 & \\
\hline \multirow[t]{6}{*}{ VI } & Adolescent & 6 & 1 & February 1 & 32 & 1.2 & \multirow{6}{*}{$8.3 \times 10^{-7}$} \\
\hline & & & 2 & March 29 & 88 & 1.1 & \\
\hline & & & 3 & June 1 & 152 & 1.5 & \\
\hline & & & 4 & August 15 & 227 & 0.9 & \\
\hline & & & 5 & September 30 & 273 & 2.1 & \\
\hline & & & 6 & November 14 & 318 & 1.7 & \\
\hline
\end{tabular}


$m_{i}=i$ th measurement of whole-body activity $(\mathrm{kBq})$ in a series from 1 up to $N$ measurements taken during the calendar year (e.g., $i=1,2, \ldots N)$, and where $\mathrm{N}-1$ is equal to zero the summation term defaults to a value of zero;

$t_{i}=$ calendar day of $i$ th measurement (e.g., $1,2, \ldots 150, \ldots$ up to $365 \mathrm{~d}^{-1}$; or $366^{-1}$ in a leap year); and

$u_{c f}=$ unit conversion factor of $8.64 \times 10^{7}$ [representing the product of $1000 \mathrm{t} \mathrm{s}^{-1}$ (or $\mathrm{Bq} \mathrm{kBq}^{-1}$ ) and $24 \mathrm{~h} \mathrm{~d}^{-1} \times 3600 \mathrm{~s} \mathrm{~h}^{-1}$.

For Example I, where only one measurement of whole-body activity $(\mathrm{kBq})$ is made (i.e., $N-1$ ), Eq. B-1 will be populated with the data shown in Table B-1 (specifically, row 1 ).

$$
A_{t}\left(\frac{\mathrm{t}}{\mathrm{y}}\right)=\left[[0.19 \mathrm{kBq} \times(274 \mathrm{~d})]+[0.19 \mathrm{kBq} \times(365 \mathrm{~d}-274 \mathrm{~d})]+\sum_{i=1}^{N-1}=0\right] \times\left(8.64 \times 10^{7} \frac{\mathrm{Bq} \mathrm{s}}{\mathrm{kBq} \mathrm{d}}\right)
$$

Because $\mathrm{N}-1$ for this example is equal to zero, the summation term (in Eq. B-1) defaults to a value of zero. Accordingly, Eq. B-1 yields the following result:

$$
A_{t}\left(\frac{\mathrm{t}}{\mathrm{y}}\right)=69.35 \frac{\mathrm{kBqd}}{\mathrm{y}} \times\left(8.64 \times 10^{7} \frac{\mathrm{Bq} \mathrm{s}}{\mathrm{kBqd}}\right)=5.99 \times 10^{9} \frac{\mathrm{t}}{\mathrm{y}} \text {, where } 1 \mathrm{~Bq}=1 \text { transformation }
$$

per second $\left(\mathrm{t} \mathrm{s}^{-1}\right)$ and so the product of the numerator $\mathrm{Bq}$ and $\mathrm{s}$ is transformations.

The number of transformations committed into the future, and which will be assigned to the year of measurement $\left(t y^{-1}\right)$, for the individual for whom the measurement applies are determined using Eq. B-2 (which is Eq. 3 in the text) and the appropriate data for this example from Table B-1 (specifically, row 1).

$$
\begin{gathered}
A_{c}=m_{N}\left[\frac{0.1}{\ln (2)} \times 2 \mathrm{~d}+\frac{0.9}{\ln (2)} \times 110 \mathrm{~d}\right] \times 1000(\mathrm{~Bq} / \mathrm{kBq}) \times(24(\mathrm{~h} / \mathrm{d}) \times 3600(\mathrm{~s} / \mathrm{h})) \quad \text { Eq. B-2 } \\
A_{\mathrm{c}}\left(\frac{\mathrm{t}}{\mathrm{y}}\right)=0.19 \mathrm{kBq} \times\left(0.288 \frac{\mathrm{d}}{\mathrm{y}}+143 \frac{\mathrm{d}}{\mathrm{y}}\right) \times\left(8.64 \times 10^{7} \frac{\mathrm{Bqs}}{\mathrm{kBqd}}\right)=2.35 \times 10^{9} \frac{\mathrm{t}}{\mathrm{y}}
\end{gathered}
$$

The transformations committed into the future are assigned to the year of measurement for the hypothetical volunteer and are combined with those transformations occurring during the measurement year. This is done by summing $A_{t}$ and $A_{c}$ using Eq. B-3 (which is equal to Eq. 4 in the text):

$$
\mathrm{A}_{\mathrm{T}}=\mathrm{A}_{\mathrm{t}}+\mathrm{A}_{\mathrm{c}} \text {, applicable to }{ }^{137} \mathrm{Cs}
$$




$$
A_{T}=5.99 \times 10^{9}+2.35 \times 10^{9}=8.34 \times 10^{9} \mathrm{ty}^{-1}
$$

The total number of transformations ( $\mathrm{t}$ ) applicable to the year of measurement can then be multiplied by the appropriate dose conversion factor (DCF; for example, Sv per transformation in the last column of first row of data in Table B-1) as shown in Eq. B-4 for an adult male (which is the same as Eq. 5 in the text).

$$
\begin{aligned}
C E D E_{\text {age group }}=A_{T} \times D C F_{\text {adult male }} & \\
\qquad E D E_{\text {age group }} & =8.34 \times 10^{9} \frac{\mathrm{t}}{\mathrm{y}} \times 1.16 \times 10^{-15} \frac{\mathrm{Sv}}{\mathrm{t}} \\
& =9.68 \times 10^{-6} \frac{\mathrm{SV}}{\mathrm{y}}
\end{aligned}
$$

The value obtained using Eq. B-4 can then be converted to mrem $\mathrm{y}^{-1}$ using the unit conversion factors appearing in Eq. B-5. This value can be used as an input term to determine the age-specific, annual TEDE (mrem $\left.\mathrm{y}^{-1}\right)$, which can then be compared to the regulatory TEDE of $15 \mathrm{mrem} \mathrm{y}^{-1}$ (and would be the only term, if only exposure to ${ }^{137} \mathrm{Cs}$ is involved).

$$
C E D E_{\text {adult male }}=9.68 \times 10^{-6} \frac{\mathrm{Sv}}{\mathrm{y}} \times 10^{2} \frac{\mathrm{rem}}{\mathrm{Sv}} \times 10^{3} \frac{\mathrm{mrem}}{\mathrm{rem}} \text { or } 0.97 \mathrm{mrem} \mathrm{y}^{-1}
$$

or about 1 mrem y $^{-1}$.

Eq. B-5

In Example II (also in Table B-1), two measurements of whole-body activity (kBq) are made (i.e., $N=2$ ) for an adult-female, hypothetical human volunteer. For this example, Eq. B-1 will be populated with the following data shown in row 2 and 3 of data in Table B-1 (Example II).

$$
A_{t}\left(\frac{t}{y}\right)=\left[\begin{array}{l}
{[0.07 \mathrm{kBq} \times(304 \mathrm{~d})]+[0.03 \mathrm{kBq} \times(365 \mathrm{~d}-348 \mathrm{~d})]+} \\
{\left[\left(\frac{0.07 \mathrm{kBq}+0.03 \mathrm{kBq}}{2}\right) \times(348 \mathrm{~d}-304 \mathrm{~d})\right]}
\end{array}\right] \times\left(8.64 \times 10^{7} \frac{\mathrm{Bq} \mathrm{s}}{\mathrm{kBqd}}\right)
$$

This arithmetic produces the following result:

$$
A_{t}\left(\frac{t}{y}\right)=\left[\left(21.28 \mathrm{kBq} \frac{\mathrm{d}}{\mathrm{y}}\right)+\left(0.51 \mathrm{kBq} \frac{\mathrm{d}}{\mathrm{y}}\right)+\left(2.20 \mathrm{kBq} \frac{\mathrm{d}}{\mathrm{y}}\right)\right] \times\left(8.64 \times 10^{7} \frac{\mathrm{Bq} \mathrm{s}}{\mathrm{kBqd}}\right)=2.07 \times 10^{9} \frac{\mathrm{t}}{\mathrm{y}}
$$


The activity that will be produced in the future (i.e., and is responsible for committed dose) for the hypothetical female volunteer in this example and assigned to the current calendar year of measurement is determined using Eq. B-2, which yields the following results:

$$
\begin{aligned}
& A_{c}=0.03\left[\frac{0.1}{\ln (2)} \times 2+\frac{0.9}{\ln (2)} \times 110\right] \times 1000 \times(24 \times 3600), \text { and so } \\
& A_{c}\left(\frac{\mathrm{t}}{\mathrm{y}}\right)=0.03\left(0.288 \frac{\mathrm{d}}{\mathrm{y}}+143 \frac{\mathrm{d}}{\mathrm{y}}\right) \times\left(8.64 \times 10^{7} \frac{\mathrm{Bqs}}{\mathrm{kBqd}}\right)=3.71 \times 10^{8} \frac{\mathrm{t}}{\mathrm{y}}
\end{aligned}
$$

The total number of committed transformations for the year of measurement is then determined using Eq. B-3.

$$
A_{\mathrm{T}}\left(\frac{\mathrm{t}}{\mathrm{y}}\right)=A_{t}+A_{c}=2.07 \times 10^{9}+3.71 \times 10^{8}=2.44 \times 10^{9} \frac{\mathrm{t}}{\mathrm{y}}
$$

Finally, the CEDE for ${ }^{137} \mathrm{Cs}$ based on two whole-body counting measurement(s) applicable to an adult female is determined using Eq. B-5, where the DCF that is applied appears in the last column of Example II data presented in Table B-1.

$$
\begin{aligned}
& \mathrm{CEDE}_{\text {age group }}=A_{T} \times D C F_{\text {adult female }} \\
& \mathrm{CEDE}_{\text {adult female }}=2.44 \times 10^{9} \frac{\mathrm{t}}{\mathrm{y}} \times 1.39 \times 10^{-15} \frac{\mathrm{Sv}}{\mathrm{t}}=3.39 \times 10^{-6} \frac{\mathrm{Sv}}{\mathrm{y}}
\end{aligned}
$$

The value obtained using Eq. B-4 can then be converted to mrem $\mathrm{y}^{-1}$ using the unit conversion factors appearing in Eq. B-5. This value can be used as an input term to determine the age-specific, annual TEDE (mrem $\mathrm{y}^{-1}$ ), which can then be compared to the regulatory TEDE of $15 \mathrm{mrem} \mathrm{y}^{-1}$ (if only exposure to ${ }^{137} \mathrm{Cs}$ is involved).

$$
\mathrm{CEDE}_{\text {adult female }}=3.39 \times 10^{-6} \frac{\mathrm{Sv}}{\mathrm{y}} \times 10^{2} \frac{\mathrm{rem}}{\mathrm{Sv}} \times 10^{3} \frac{\mathrm{mrem}}{\mathrm{rem}} \approx 0.3 \mathrm{mrem} \mathrm{y}^{-1}
$$

Example III shows how to compute the CEDE age group for ${ }^{137} \mathrm{Cs}$ based on multiple (six) whole-body counting measurements performed for a hypothetical teenager during a measurement year. 


$$
A_{t}\left(\frac{\mathrm{t}}{\mathrm{y}}\right)=\left[\begin{array}{l}
{[0.700 \mathrm{kBq} \times(152 \mathrm{~d})]+[0.523 \mathrm{kBq} \times(365 \mathrm{~d}-340 \mathrm{~d})]+} \\
{\left[\left(\frac{0.700 \mathrm{kBq}+0.781 \mathrm{kBq}}{2}\right) \times(214 \mathrm{~d}-152 \mathrm{~d})\right]+} \\
{\left[\left(\frac{0.781 \mathrm{kBq}+0.756 \mathrm{kBq}}{2}\right) \times(246 \mathrm{~d}-214 \mathrm{~d})\right]+} \\
{\left[\left(\frac{0.756 \mathrm{kBq}+0.742 \mathrm{kBq}}{2}\right) \times(277 \mathrm{~d}-246 \mathrm{~d})\right]+} \\
{\left[\left(\frac{0.742 \mathrm{kBq}+0.603 \mathrm{kBq}}{2}\right) \times(309 \mathrm{~d}-277 \mathrm{~d})\right]+} \\
{\left[\left(\frac{0.603 \mathrm{kBq}+0.523 \mathrm{kBq}}{2}\right) \times(340 \mathrm{~d}-309 \mathrm{~d})\right]}
\end{array}\right] \times\left(8.64 \times 10^{7} \frac{\mathrm{Bq} \mathrm{s}}{\mathrm{kBq}}\right),
$$

Such that for this example; $A_{t}=2.18 \times 10^{10} \frac{\mathrm{t}}{\mathrm{y}}$

The activity that will be produced in the future for this hypothetical volunteer, and assigned to the current calendar year of measurement, is determined using Eq. B-2 and yields the following results.

$$
\begin{aligned}
& A_{C}=0.523\left[\frac{0.1}{\ln (2)} \times 2 \mathrm{~d}+\frac{0.9}{\ln (2)} \times 110 \mathrm{~d}\right] \times 1000 \times(24 \times 3600), \text { and } \\
& A_{c}=0.523\left[\frac{0.1}{\ln (2)} \times 2+\frac{0.9}{\ln (2)} \times 110\right] \times 1000 \times(24 \times 3600)=6.47 \times 10^{9} \frac{\mathrm{t}}{\mathrm{y}}
\end{aligned}
$$

The total number of committed transformations for the year of measurement is then determined using Eq. B-3.

$$
A_{T}\left(\frac{\mathrm{t}}{\mathrm{y}}\right)=A_{t}+A_{c}=2.18 \times 10^{10}+6.47 \times 10^{9}=2.83 \times 10^{10} \frac{\mathrm{t}}{\mathrm{y}}
$$

Finally, for this example the CEDE for ${ }^{137} \mathrm{Cs}$ based on six whole-body counting measurement(s) applicable to a teenager is determined using Eq. B-5:

$$
\mathrm{CEDE}_{\text {Teenager }}=A_{T} \times \mathrm{DCF}_{\text {Teenager }}=2.83 \times 10^{10} \times 1.41 \times 10^{-15}=3.99 \times 10^{-5} \frac{\mathrm{Sv}}{\mathrm{y}}
$$

The value obtained using Eq. B-4 can then be converted to mrem $\mathrm{y}^{-1}$ using the unit conversion factors appearing in Eq. B-5. This value can be used as an input term to determine the age-specific, annual TEDE (mrem $\left.\mathrm{y}^{-1}\right)$, which can then be compared to the regulatory TEDE of $15 \mathrm{mrem} \mathrm{y}^{-1}$ (if only exposure to ${ }^{137} \mathrm{Cs}$ is involved). 


$$
\mathrm{CEDE}_{\text {Teenager }}=3.99 \times 10^{-5} \frac{\mathrm{Sv}}{\mathrm{y}} \times 10^{2} \frac{\mathrm{rem}}{\mathrm{Sv}} \times 10^{3} \frac{\mathrm{mrem}}{\mathrm{rem}} ; \text { or approximately } 4 \mathrm{mrem} \mathrm{y}^{-1} \text {. }
$$

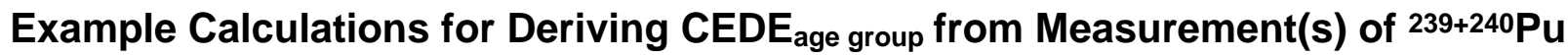 Activity Excreted in a 24-h Urine Void}

For AMS measurement(s) of ${ }^{239+240} \mathrm{Pu}$ in one or more $24-\mathrm{h}$ urine void(s) over a calendar year for a hypothetical adult, teenager, or adolescent volunteer enrolled in the Marshall Islands radiological surveillance monitoring program, the annual CEDE $E_{\text {age group }}$ can be calculated using the following two-step approach.

First, ${ }^{239+240} \mathrm{Pu}$ activity $\left(\mu \mathrm{Bq} \mathrm{y} \mathrm{y}^{-1}\right)$ excreted in urine for the entire calendar year of measurement(s) is determined for the individual. This is done using Eq. B-1 (which is the same as Eq. 1 in the text).

Next, total annual activity in urine is multiplied by the applicable $\mathrm{CF}_{\mathrm{CEDE}}$ obtained from the last column of data in Table B-2.

This approach is put into practice in the following three additional examples (see Table B-2), which pertain to 1) an adult for which a single measurement of ${ }^{239+240} \mathrm{Pu}$ excreted in urine is made during a 365-d calendar year; 2) a teenager for which two measurements of ${ }^{239+240} \mathrm{Pu}$ excreted in urine are made during a 365-d calendar year; and 3) an adolescent for which six measurements of ${ }^{239+240} \mathrm{Pu}$ excreted in urine are made during a 365-d calendar year.

For the adult for which a single measurement of ${ }^{239+240} \mathrm{Pu}$ in urine is made (see Example IV in first row of data in Table B-2), the activity for the year of measurement for this hypothetical human volunteer is found using Eq. B-1 without the units conversion factor $\left(u_{c f}\right)$ and using as input the daily activity of ${ }^{239+240 P u}\left(\mu \mathrm{Bq} \mathrm{d}^{-1}\right)$ measured in the urine sample(s) (which is consistent with Eq. 1a found prior to Eq-6 in text), i.e.,

$$
A_{t}\left(\frac{\mu \mathrm{Bq}}{\mathrm{y}}\right)=\left[\left[1.0 \frac{\mu \mathrm{Bq}}{\mathrm{d}} \times(210 \mathrm{~d})\right]+\left[1.0 \frac{\mu \mathrm{Bq}}{\mathrm{d}} \times(365 \mathrm{~d}-210 \mathrm{~d})\right]+\sum_{i=1}^{N-1}=0\right]
$$


Again, because $N-1$ in this case is equal to zero, the summation term defaults to a value of zero. Consequently, this equation yields the following result;

$$
A_{t}=(1.0 \times 210)+[1.0 \times(365-210)]+0=365 \frac{\mu \mathrm{Bq}}{\mathrm{y}}
$$

The $\mathrm{CEDE}_{\text {age group }}$ is determined for this example by multiplying the annual activity by the applicable $\mathrm{CF}_{\mathrm{CEDE}}$ (Sv per $\mu \mathrm{Bq} \mathrm{y}^{-1}$ ), which appears in last column of Example IV in Table B-2. This value can serve as an input term to determine the age-specific, annual TEDE (mrem $\mathrm{y}^{-1}$ ), which can then be compared to the regulatory TEDE of 15 mrem $\mathrm{y}^{-1}$ (and would be the only term, if only exposure to ${ }^{239+240} \mathrm{Pu}$ is involved). Using the equation:

$$
\begin{aligned}
\operatorname{CEDE}_{\text {Adult }}= & A_{t} \times \mathrm{CF}_{\mathrm{CEDE}(\text { age group) }} \\
& \operatorname{CEDE}_{\text {Adult }}=365 \frac{\mu \mathrm{Bq}}{\mathrm{y}} \times 3.3 \times 10^{-7} \frac{\mathrm{Sv}}{\mu \mathrm{Bq} / \mathrm{y}}=1.2 \times 10^{-4} \mathrm{~Sv}
\end{aligned}
$$

This example yields an annual TEDE for the year of measurement of $1.2 \times 10^{-2} \mathrm{rem} \mathrm{y}^{-1}$ or $12 \mathrm{mrem} \mathrm{y}^{-1}$ (refer to related discussion on the use of an annualized TEDE on p. 5 and 6 based on 100 rem per Sv).

For the next example (see Example $\mathrm{V}$ in Table B-2) a teenager is considered to be the hypothetical human volunteer and to provide two 24-h urine voids for analysis of

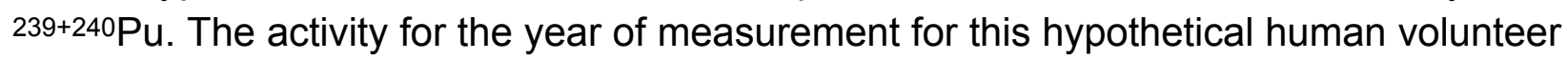
is found using Eq. B-1 without using the units conversion factor (which is consistent with Eq. $1 \mathrm{a}$ in text), i.e.,

$$
A_{t}\left(\frac{\mu \mathrm{Bq}}{\mathrm{y}}\right)=\left[\begin{array}{l}
\left.\left[2.0 \frac{\mu \mathrm{Bq}}{\mathrm{d}} \times(94 \mathrm{~d})\right]+\left[3.1 \frac{\mu \mathrm{Bq}}{\mathrm{d}} \times(365 \mathrm{~d}-302 \mathrm{~d})\right]+\right] \\
{\left[\frac{2.0+3.1}{2} \frac{\mu \mathrm{Bq}}{\mathrm{d}} \times(302 \mathrm{~d}-94 \mathrm{~d})\right]}
\end{array}\right]
$$

This equation yields the following result:

$$
A_{t}=9.14 \times 10^{2} \frac{\mu \mathrm{Bq}}{\mathrm{y}}
$$

The $\mathrm{CEDE}_{\text {age group }}$ is determined for this example by multiplying the annual activity excreted in the urine by the applicable $\mathrm{CF}_{\mathrm{CEDE}}\left(\mathrm{Sv}\right.$ per $\mu \mathrm{Bq}^{\mathrm{y}^{-1}}$ ) for this example (see last column of data in Table B-2). This value can serve as an input term to determine the 
age-specific, annual TEDE (mrem $\mathrm{y}^{-1}$ ), which can then be compared to the regulatory

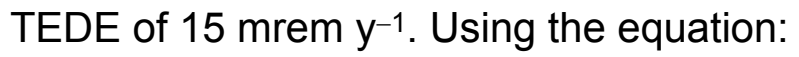

$$
\begin{aligned}
& \mathrm{CEDE}_{\text {Teenager }}=A_{t} \times C F_{\text {CEDE (age, group })} \\
& \mathrm{CEDE}_{\text {Teenager }}=914 \frac{\mu \mathrm{Bq}}{\mathrm{y}} \times 5.0 \times 10^{-7} \frac{\mathrm{Sv}}{\mu \mathrm{Bq} / \mathrm{y}}=4.6 \times 10^{-4} \mathrm{~Sv}
\end{aligned}
$$

This example yields an annual TEDE for year of measurement of $4.6 \times 10^{-2} \mathrm{rem} \mathrm{y}^{-1}$ (based on 100 rem per Sv) or $46 \mathrm{mrem} \mathrm{y}^{-1}$.

For the last example (see Example VI in Table B-2) an adolescent is considered to be the hypothetical human volunteer and to provide six 24-h urine voids for analysis of

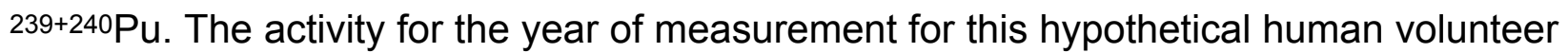
is found using Eq. B-1, without using the units conversion factor (which is consistent with Eq. 1a in text). In this example;

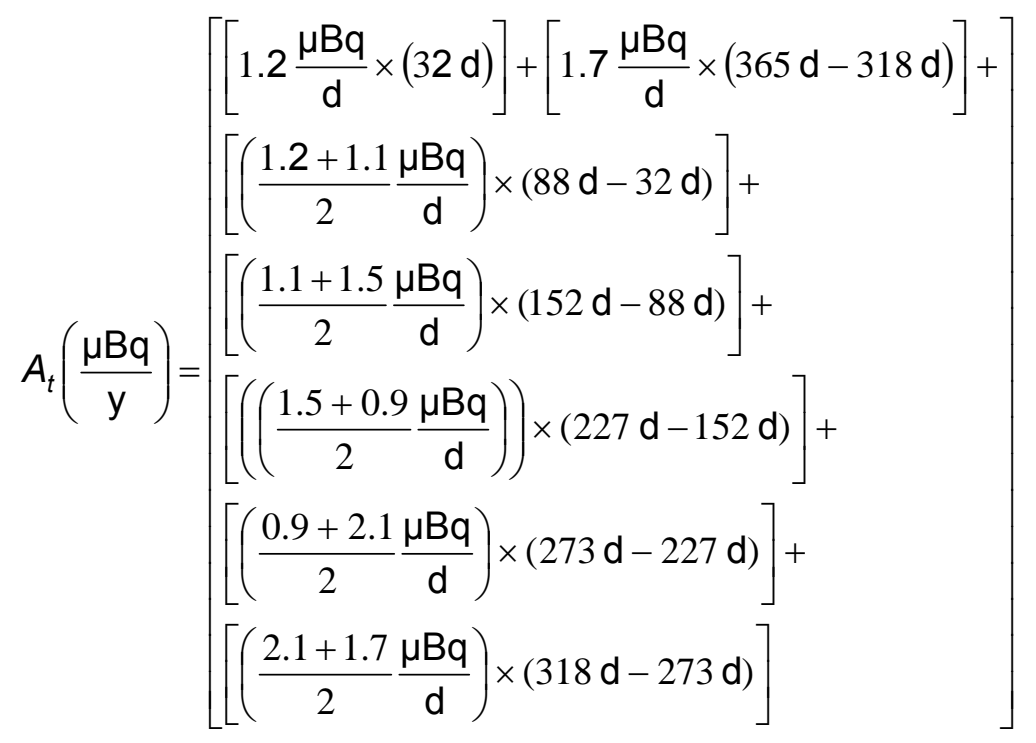

This equation yields the following result:

$$
A_{t}=5.1 \times 10^{2} \frac{\mu \mathrm{Bq}}{\mathrm{y}}
$$

The $\mathrm{CEDE}_{\text {age group }}$ is determined for this last example by multiplying the annual activity excreted in the urine by the applicable $\mathrm{CF}_{\mathrm{CEDE}}\left(\mathrm{Sv}\right.$ per $\left.\mu \mathrm{Bq}^{-1}\right)$ for this example. The applicable $\mathrm{CF}_{\mathrm{CEDE}}$ can be found in the last column of Example VI data in Table B-2. This value can serve as an input term to determine the age-specific, annual TEDE 
(mrem $\left.\mathrm{y}^{-1}\right)$, which can then be compared to the regulatory TEDE of 15 mrem $\mathrm{y}^{-1}$. Using the equation:

$$
\begin{aligned}
& \mathrm{CEDE}_{\text {Adolescent }}=A_{t} \times \mathrm{CF}_{\mathrm{CEDE}(\text { age group) }} \\
& \mathrm{CEDE}_{\text {Adolescent }}=510 \frac{\mu \mathrm{Bq}}{\mathrm{y}} \times 8.3 \times 10^{-7} \frac{\mathrm{Sv}}{\mu \mathrm{Bq} / \mathrm{y}}=4.2 \times 10^{-4} \mathrm{SV}
\end{aligned}
$$

This example yields an annual TEDE for the year of measurement of $4.2 \times 10^{-2} \mathrm{rem} \mathrm{y}^{-1}$ (based on 100 rem per Sv) or $42 \mathrm{mrem} \mathrm{y}^{-1}$. 


\section{APPENDIX C}

\section{Marshall Islands Dosimetry for Plutonium Isotopes in Urine for Calendar Years 1988 through 2004}

The measurements of ${ }^{239} \mathrm{Pu}$ and ${ }^{240} \mathrm{Pu}$ by $\mathrm{AMS}$ in a $24-\mathrm{h}$ void of urine indirectly reflect the presence of these plutonium isotopes in the body at the time of excretion. Specifically, this plutonium elimination rate, which can be described in units of activity and expressed as micro-Becquerel $(\mu \mathrm{Bq})$ of ${ }^{239+240} \mathrm{Pu}$ (combined) activity excreted (lost) per day, is referenced back to the amount of $239+240 \mathrm{Pu}$ activity in the body at the time of measurement by biokinetic relationships. This appendix provides an applied method for evaluating the dose from ${ }^{239+240} \mathrm{Pu}$ based on urinary excretion measurements. This method of dose evaluation was applied to measurement data collected from volunteers from 1998 to 2004. As noted in Appendix B, this procedure was replaced beginning in 2005 by one that is more in agreement with currently accepted dosimetry used by the U.S. Department of Energy (AJC \& Associates, Inc., 2004). Like the method described in Appendix B, calculations made using this procedure were designed to yield conservative dose estimates and were also subject to thresholds for performing further investigations. 


\section{Terminology}

The organs of the body that do not have a direct external input source (i.e., food, water, air) are "systemic" organs. Collectively these organs are the systemic compartment. Within the "systemic" compartment are specific organ or tissue compartments each of which contains a fraction of any activity deposited in the systemic compartment.

\section{Biokinetic Relationship}

The method of determining the systemic content of plutonium assumes that $50 \%$ of the plutonium deposited in the body is eventually eliminated via the urinary excretion pathway. Under equilibrium conditions, the amount of plutonium eliminated via the urinary pathway is one-half of the steady-state levels of plutonium in the systemic compartment. Therefore, for every Becquerel $(\mathrm{Bq})$ measured in the urine, there are two Becquerel of plutonium in the systemic compartment. To maintain a steady state of $2 \mathrm{~Bq}$ in the systemic compartment, an input of $2 \mathrm{~Bq}$ must also occur. The input assumes deposition into the lung via the inhalation pathway. Most compartments within the lung have a rapid turnover and provide a minor contribution to the dose. However, the lung compartments that supply the bulk of the plutonium to the systemic compartment are longer-term compartments that will, under steady state conditions, maintain a $2 \mathrm{~Bq}$ inventory and will contribute the greatest amount of dose to the lung. These steady state relationships are illustrated in Fig. C-1.

\section{Dosimetry}

Systemic organs that receive the majority of the dose from plutonium or are of particular dosimetric concern are bone, liver, and gonads. Under steady state conditions, systemic plutonium partitions $(f)$ are $0.5,0.5$, and 0.0035 for the bone, liver, and gonads, respectively. Thus for a constant steady-state activity of plutonium, the number of transformations during the year in the systemic organs is given by Eq. C-1:

$$
\begin{aligned}
& T_{\text {organ }}=A_{\text {systemic }} \times f_{\text {organ }} \times 365 \frac{\mathrm{d}}{\mathrm{y}} \times 8.64 \times 10^{4} \frac{\mathrm{s}}{\mathrm{d}} \text {, where } \\
& T_{\text {organ }}=\text { number of transformations that occur in the organ during the year of } \\
& \text { measurement, and } \\
& A_{\text {systemic }}=\text { total systemic activity associated with }{ }^{239+240 \mathrm{Pu}(\mathrm{Bq}) .}
\end{aligned}
$$


Figure C-1. Equilibrium Assumptions for Plutonium Dosimetry using only Urinary Excretion Data.

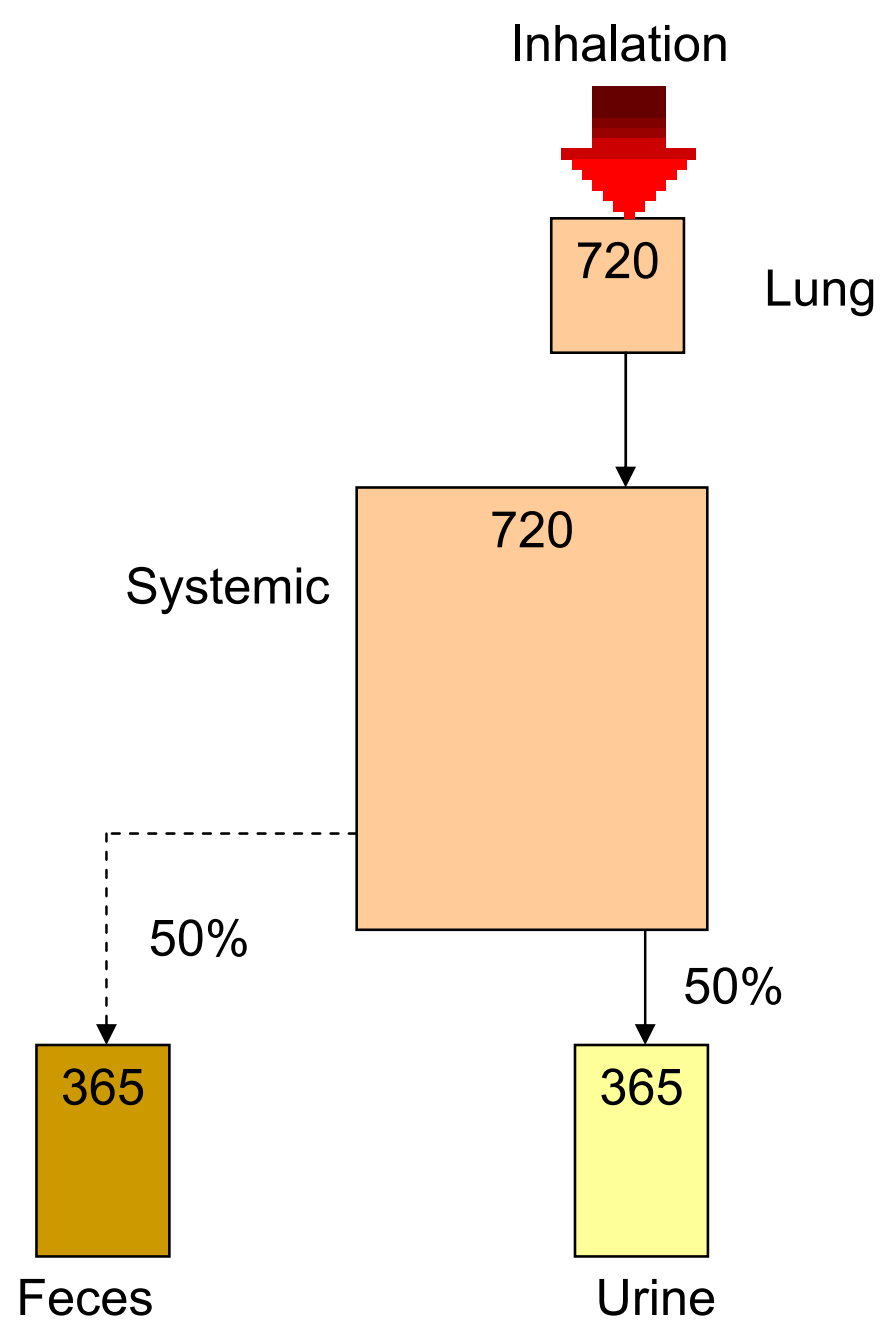

\section{Example:}

If $1 \mathrm{~Bq}$ day $^{-1}$ is excreted in the urine over the year (365 days), then under equilibrium conditions (i.e., input rate equals output rate) the systemic compartment would contain $720 \mathrm{~Bq}$ of activity that is divided among the major systemic organs.

The long term retention compartments of the Lung are considered to be at equilibrium with the systemic compartment and are the primary input to the compartment. Therefore, the long term compartments of the lung contain the same activity as the systemic compartment. 
Similarly, the number of transformations in the lungs can be computed using Eq. C-2:

$T_{\text {Lung }}=A_{\text {Lung }} \times 365 \frac{\mathrm{d}}{\mathrm{y}} \times 86400 \frac{\mathrm{s}}{\mathrm{d}}$

Eq. C-2

$T_{\text {Lung }}=$ Transformations ( $\mathrm{t}$ ) per year for a critical organ (e.g., lung); and

$A_{\text {Lung }}=$ Activity ( $\left.t / s\right)$ in critical organ (e.g., lung)

The annual dose to each organ is evaluated using the transformations derived for each organ (see Eq. C-3):

$D E_{\text {organ }}=1.6 \times 10^{-10} \frac{\mathrm{J} \mathrm{g}}{\mathrm{MeV} \mathrm{kg}} \times T_{\text {organ }} \frac{\mathrm{t}}{\mathrm{y}} \times \mathrm{SEE} \times \frac{1 \mathrm{~Gy}}{\mathrm{~J} / \mathrm{kg}}$, where

Eq. C-3

$D E_{\text {organ }}=$ the dose equivalent to the organ (Gy), and

SEE = specific effective energy (as obtained from and defined by the ICRP; $\frac{\mathrm{MeV}}{\mathrm{g} \mathrm{t}^{1}}$

ICRP weighting factors convert the dose equivalent to the effective dose equivalent (EDE). These weighting factors and the SEE values used for calculations described in this appendix are provided in Table C-1.

The effective dose equivalent (EDE) for the organ is computed from Eq. C-4:

$E D E_{\text {organ }}=D E_{\text {organ }} \times W_{T}\left(\right.$ see Table C-1, column 2 for definition of $\left.\mathrm{w}_{\mathrm{T}}\right) \quad$ Eq. C-4

Table C-1. ICRP specific effective energy (SEE) and weighting factors $\left(w_{T}\right)$ used for Marshall Islands Pu dosimetry prior to 2005.

\begin{tabular}{ccc}
\hline Organ & ICRP Weighting Factor $\left(w_{\mathrm{T}}\right)$ & $\mathrm{SEE}\left(\frac{\mathbf{M e V}}{\mathbf{g ~ t}}\right)$ \\
\hline Lung & 0.12 & 0.1 \\
Liver & 0.06 & 0.058 \\
Bone & 0.03 & 0.21 \\
Gonads & 0.25 & 3 \\
\hline
\end{tabular}

\footnotetext{
${ }^{1} \mathrm{SEE}$ values for ${ }^{239} \mathrm{Pu}$ and ${ }^{240} \mathrm{Pu}$ are approximately the same value.
} 
The annual effective dose equivalent for the measured intake is equal to the sum of the organ effective dose equivalents:

$$
E D E_{\text {Annual }}=E D E_{\text {Lung }}+E D E_{\text {Liver }}+E D E_{\text {Bone }}+E D E_{\text {Gonads }} \quad \text { Eq. C-5 }
$$

Under steady state conditions, the annual effective dose equivalent will be committed for each year. The committed effective dose equivalent (CEDE) under steady-state conditions over a 70-y life span of time is determined using Eq. C-6:

$$
C E D E_{70}=E D E_{\text {Annual }} \times 70 \mathrm{y}
$$

The following assumptions apply to the computation of the $\mathrm{CEDE}_{70}$ :

- Intake via inhalation,

- Chronic exposure,

- Continuous (steady state) intake rate, and

- All compartments are in equilibrium

This analysis accounts for the committed dose from the time of measurement to 70 years in the future. Doses from samples collected in subsequent year doses are computed without correction for residual activity from previous doses. This mode of subsequent year computation is highly conservative and will tend to over-estimate lifetime doses. Doses prior to the first bioassay measurement are not implied or evaluated in this analysis. Multiple samples are rarely obtained within the same year, however, if multiple samples were obtained, the total transformations used in the dose computations are computed from time weighted systemic and lung activity values.

\section{Age-Dependent Dosimetry}

Internally deposited alpha particles comprise most of the dose delivered from plutonium. These particles have a short range and tend to deposit all of their energy into the organ of uptake. When computing the SEE, ICRP incorporated the weight of the organ as divisor. Therefore, an age adjustment can be performed by multiplying the SEE by a ratio of the adult to the organ mass in the age group of interest. The organmass ratios used in the calculations described in this appendix appear in Table C-2. 
Table C-2. Lists of adult to age-group of interest organ-mass ratios used for SEE adjustment factors for age-dependent dose calculations.

\begin{tabular}{clccc}
\hline Organ & Adult & $\begin{array}{c}\text { Teenager } \\
\mathbf{( 1 5} \mathbf{y})\end{array}$ & $\begin{array}{c}\text { Pre-teenager } \\
\mathbf{( 1 0} \mathbf{y})\end{array}$ & $\begin{array}{c}\text { Adolescent } \\
\mathbf{( 5} \mathbf{~ y})\end{array}$ \\
\hline Lung & 1.00 & 1.54 & 2.21 & 3.45 \\
Liver & 1.00 & 1.29 & 2.03 & 3.08 \\
Bone & 1.00 & 1.00 & 1.76 & 3.24 \\
Gonads & 1.00 & 2.26 & 18.52 & 21.47 \\
\hline
\end{tabular}



University of California

Lawrence Livermore National Laboratory

Technical Information Department

Livermore, CA 94551

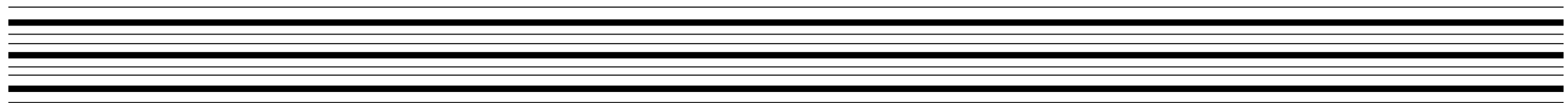

